\title{
Behavior-Based Scale Definitions for Determining Individual Space Use: Requirements of Two Amphibians
}

\author{
Lukas Indermaur, ${ }^{1, *}$ Marianne Gehring, ${ }^{1, \dagger}$ Wendelin Wehrle, ${ }^{1, \neq}$ Klement Tockner, ${ }^{2,3, \S}$ and Beat Naef-Daenzer ${ }^{4, \|}$
}

1. Swiss Federal Institute of Aquatic Science and Technology (Eawag), Department of Aquatic Ecology, Überlandstrasse 133, 8600 Dübendorf, Switzerland, and Swiss Federal Institute of Technology (ETH), Institute of Integrative Biology, 8092 Zürich, Switzerland;

2. Leibnitz-Institute of Freshwater Ecology and Inland Fisheries (IGB), Mueggelseedamm 310, 12587 Berlin, Germany;

3. Institute of Biology, Free University, Berlin, Germany;

4. Swiss Ornithological Institute, 6203 Sempach, Switzerland

Submitted April 5, 2008; Accepted July 28, 2008;

Electronically published December 8, 2008

Online enhancements: figures, tables.

AвSTRACT: Understanding individual space use remains a major issue in ecology, and it is complicated by definitions of spatial scale and the interplay of multiple factors. We quantified the effect of habitat and biotic and individual factors on space use by amphibians (Bufo bufo spinosus $[\mathrm{BB}]$ and Bufo viridis [BV]) that were radiotracked in their terrestrial summer habitat. We analyzed two spatial scales, 50\% core areas and 95\% home ranges (excluding 50\% core areas), thought to represent resting and foraging areas, respectively. The $50 \%$ core area of $\mathrm{BB}$ was best explained by habitat structure and prey density, whereas the $50 \%$ core area of BV was determined solely by habitat structure. This suggests that the resting and foraging areas of BB are not spatially separated. The $95 \%$ home range of BB was determined by prey density, while for BV both habitat structure and prey density determined home range size. We conclude that the terrestrial area requirements of amphibians depend on the productivity and spatiotemporal complexity of landscapes and that differential space use may facilitate their co-occurrence. Behavior-based a priori hypotheses, in combination with an information-theoretic approach and path analyses, provide a promising framework to dis-

* Corresponding author; e-mail: lukas.indermaur@eawag.ch.

† E-mail: mariannegehring@yahoo.de.

¥ E-mail: w.wehrle@access.unizh.ch.

${ }^{\S}$ E-mail: tockner@igb-berlin.de

"| E-mail: beat.naef@vogelwarte.ch.

Am. Nat. 2009. Vol. 173, pp. 60-71. (C) 2009 by The University of Chicago. 0003-0147/2009/17301-50366\$15.00. All rights reserved.

DOI: $10.1086 / 593355$ entangle factors that govern individual space use, thereby advancing home range studies.

Keywords: Bufo, home range size, floodplain mosaic, foraging behavior, habitat structure, path analysis.

\section{Introduction}

Home range size, accommodating all behaviors related to reproduction and survival (Burt 1943), has been used as an indicator of energy expenditure (Schoener 1968) and animal performance (Kenward 1985). These factors are in turn linked to key parameters of population dynamics. For example, with decreasing home range size, population density and dispersal rate are predicted to increase (Kjellander et al. 2004; Wang and Grimm 2007). Thus, home range size is a general variable for studying spatially structured populations, and it is informative for population management (Lomnicki 1988).

Among species, variation in home range size is strongly related to body size (McNab 1963; Biedermann 2003). Among individuals, variation in home range size may be influenced by food availability and competition (Ebersole 1980), predation risk (Lima and Dill 1990), cover (Tufto et al. 1996), and differences among individuals (Börger et al. 2006b). Furthermore, habitat structure-for example, habitat composition, configuration, and connectivity-is related to the distribution of resources and shelter (Prohl and Berke 2001). However, the effects of habitat structure and resources on home range size have rarely been untangled (but see Tufto et al. 1996; Lombardi et al. 2007). Habitat structure per se may constrain or facilitate access to resources (Arthur et al. 1996; Revilla et al. 2004), and the distribution of the preferred habitat type may have a dominating effect on space use (Pasinelli 2000; Buner et al. 2005), suggesting a close link between habitat selection and home range size. In this study, we therefore include factors for overall habitat structure (e.g., habitat richness) and partial habitat structure (area of preferred habitat type) and food resources to quantify their separate effects on home range size.

Home range size is usually quantified using a single 
spatial scale, for example, the area including 95\% of either raw locations or a calculated utilization distribution (Worton 1989). Animals, however, do not use home ranges uniformly. The intensity of use is higher within core areas than in the peripheral parts of the home range, which may reflect the spatial segregation of behaviors (Marzluff et al. 2001). Consequently, the ecological relevance of the key underlying factors may vary with spatial scale (Börger et al. 2006b). Hence, we need multiple spatial scales when quantifying variation in home range size. We propose to define the spatial scales at which to study variation in home range size by the behaviors they probably integrate. This novel approach allows the formulation of a priori hypotheses on how the impact of factors is expected to vary with scale and behavior, facilitating our understanding of spatially structured populations.

Dynamic floodplains comprise a spatially complex habitat mosaic (Naiman et al. 2005) and are therefore good model systems to study the impacts of habitat factors (e.g., habitat richness, temperature) and biotic factors (food resources) on individual space use. We used two amphibian species (common toad Bufo bufo spinosus and green toad Bufo viridis), differing in life history and ecology, to shed more light on the processes structuring terrestrial summer home ranges. The two toad species co-occur within the active tract of a naturally dynamic floodplain (Tockner et al. 2006). Our main goal was to quantify direct and indirect effects of habitat, biotic, and individual factors on the sizes of $50 \%$ core areas and $95 \%$ home ranges.

We focus on the terrestrial summer period because of its importance for the viability of amphibian populations (Trenham and Shaffer 2005; Rittenhouse and Semlitsch 2007) and because it narrows the set of factors that influence space use. During the summer period, amphibians need abundant food to build up fat reserves for maintenance and future reproduction (Wälti and Reyer 2007) as well as refugia from desiccation (Schwarzkopf and Alford 1996; Seebacher and Alford 2002). Hence, resting and foraging are the dominating behaviors in summer that may segregate spatially. We therefore expect that toads use the $50 \%$ core areas within home ranges for resting while they use the peripheral areas of $95 \%$ home range (excluding $50 \%$ core areas) for foraging. Based on these assumptions we formulated three hypotheses that are expected to apply to both species.

1. Habitat factors (habitat structure, home range temperature) control the size of $50 \%$ core areas. We expect the $50 \%$ core areas to decrease with increasing habitat structure (e.g., area of large wood, habitat richness; Kie et al. 2002; McLoughlin et al. 2003; Buner et al. 2005), as well as to decrease with increasing temperature (Schwarzkopf and Alford 1996; Seebacher and Alford 2002).

2. Biotic factors (prey density and competition) control the size of $95 \%$ home ranges. We expect the size of $95 \%$ home ranges to decrease with increasing food density and competition (McNab 1963; Hixon 1980).

3. The effects of individual factors (body mass, sex, animal identity) on 50\% core areas and 95\% home ranges are predicted to be outweighed by habitat and biotic factors. Body mass is likely a poor explanatory factor as fluctuations in body mass are primarily caused by evaporation and adsorption of water rather than by food intake. The reproductive status (sex; Lombardi et al. 2007) and differences among individuals (Steury and Murray 2003) are considered less important during the nonbreeding season.

Our emphasis on behavior-based a priori hypotheses for determining space use by individuals contributes to a better grounding of home range studies in theory. The statistical approaches applied here provide a promising analytical framework to untangle the web of factors that govern space use, thereby advancing our understanding of spatially structured populations.

\section{Methods \\ Study Site}

The study was conducted from mid-June until the end of September in 2005 and 2006, along the seventh-order Tagliamento River in northeastern Italy $\left(46^{\circ} \mathrm{N}, 12^{\circ} 30^{\prime} \mathrm{E}\right)$. The Tagliamento (catchment area: $2,580 \mathrm{~km}^{2}$ ) originates at $1,000 \mathrm{~m}$ asl in the southern fringe of the European Alps and flows almost unimpeded for $172 \mathrm{~km}$ to the Adriatic Sea. The river retains its natural morphological and hydrological characteristics.

The main study area was the active tract $\left(1.6 \mathrm{~km}^{2}\right)$ of an island-braided floodplain complex (at river kilometer $79.8-80.8 ; 135 \mathrm{~m}$ asl). This reach contains a spatially complex and temporally dynamic habitat mosaic embedded in an extensive matrix of exposed riverine sediments (Petts et al. 2000; fig. A1, in app. A in the online edition of the American Naturalist).

The 800 -m-wide active tract is bordered by riparian forest on the north bank and the steep slope of Monte Ragogna on the south bank. Further detailed information on the Tagliamento catchment and the main study area can be found elsewhere (Ward et al. 1999; Arscott et al. 2002; Tockner et al. 2003).

\section{Study Species}

Bufo bufo spinosus is a generalist species associated with densely vegetated habitats, while Bufo viridis is a pioneer species of the continental and Mediterranean steppes (Giacoma and Castellano 2006). Bufo viridis is a quick colonizer of pioneer habitats and far more versatile than B. b. spi- 
nosus. Both toad species may burrow to withstand harsh environmental conditions and for hydration (Hoffman and Katz 1989). Bufo b. spinosus is considered less tolerant of high temperature than B. viridis (Degani et al. 1984; Meek and Jolley 2006).

\section{Habitat Mapping}

In 2005 and 2006, the entire study area was mapped in detail at base flow (about $20 \mathrm{~m}^{3} \mathrm{~s}^{-1}$ ) using a differential global positioning system (GPS) device (Trimble GeoXT, Zurich), and data were processed using ArcView GIS 9.0 (ESRI, Redlands, CA). Seven habitat types were discriminated: exposed gravel sediments (63.9 ha; averaged values for both years), water (13.5 ha), established islands (woody vegetation $>2 \mathrm{~m}$ tall, topographically elevated, $\geq 1 \mathrm{~m}^{2} ; 8.3$ ha), open pioneer vegetation (cover $10 \%$ to $\leq 50 \%$; 6.3 ha), dense pioneer vegetation (cover $>50 \%$; $3.9 \mathrm{ha}$ ), large wood deposits $\left(\geq 0.5 \mathrm{~m}^{2} ; 1.2 \mathrm{ha}\right.$ ), and eroded banks (ecotones of established islands providing many earth holes as refuges, with slopes between $45^{\circ}$ and $90^{\circ}$; $0.3 \mathrm{ha}$ ).

\section{Radio Telemetry}

Adult toads were caught during random searches at night, weighed, and fitted with radio transmitters LT2-351 (2 g) or LT2-392 (5 g; Titley Electronics, Ballina, Australia). Transmitters were tightly fitted around the toads' waists and secured with an aluminum beaded-chain belt (Ball Chain Manufacturing, Mount Vernon, NY; Rathbun and Murphey 1996; fig. A2).

The mass of the transmitter, including the belt, did not exceed $10 \%$ of the body mass (mean \pm SD: B. b. spinosus, $4.32 \% \pm 1.51 \%$; B. viridis, $6.86 \% \pm 0.94 \%)$, as recommended by Richards et al. (1994). At the start of the study, all toads were sexed and photographed to allow individual identification if a transmitter tag was lost. All toads were reweighed to the nearest $0.1 \mathrm{~g}$ at weekly to biweekly intervals during the study period to monitor individual body condition. Neither transmitter mass nor duration of the tracking period negatively affected changes in the toads' body mass (Indermaur et al. 2008).

Scanning receivers (Australis 26k) and handheld antennas (Yagi AY/C, Yagi collapsible) were used for tracking the toads (Titley Electronics, Ballina, Australia). We followed each of 56 radio-tagged B. b. spinosus and 59 B. viridis for 1-3 months (B. b. spinosus: mean 44.5 days, range 13.4-99.5 days; $B$. viridis: mean 33.1 days, range 13.5-71 days). The exact position of each toad was recorded 6 days per week, once daily and once nightly, using a GPS device (average tracking resolution: $1 \mathrm{~m}$ ). Two observers simultaneously located toads in different parts of the study area, randomly varying the tracking time and the sequence of tracked animals. For more details on the telemetry methods, see appendix B in the online edition of the American Naturalist.

\section{Estimation of Home Range Size}

For home range estimation, a total of 3,079 locations of B. b. spinosus and 2,545 locations of $B$. viridis were collected (mean number of locations \pm SD: B. b. spinosus, $55 \pm$ 27.6; B. viridis, $43 \pm 16$ ). A preliminary analysis (incremental plots; Hayne 1949) of the relationship between the number of locations and home range estimates showed that 20 locations of $B . b$. spinosus and 25 locations for $B$. viridis were required to obtain robust individual home range size estimates. Because the number of locations was at least twice as high as the calculation locations, we consider that our estimates were robust.

Fixed-kernel home ranges were calculated with Ranges 7 software (grid: $160 \times 160$ cells; cell size: $1 \mathrm{~m}^{2}$ ), using the $50 \%$ or $95 \%$ contours of the density distribution (South et al. 2005). We omitted the outer $5 \%$ of the data. Their inclusion would have extended contours into areas that were not used repeatedly for daily activities but rather for explorative behavior, thereby introducing bias in home range size estimates (Kenward 2001). Toads were considered to use the interior core of home ranges for resting and their periphery for foraging, depicted by the $50 \%$ and $95 \%$ contours, respectively. These spatial scales were discriminated for each species separately by applying a regression of probability of use against the proportion of total area (fig. A3; Clutton-Brock et al. 1982; Powell 2000).

The average smoothing factor $(\mathrm{h}=0.3)$ was leastsquares cross-validated using Ranges 7, validated by our field observations, and applied to all individuals of both species. Because B. viridis avoided established islands and the riparian forest, we fitted the $95 \%$ contours of $B$. viridis as they touched the boundaries of these habitat types, and we compared the congruency of the empirically fitted contour with the analytically derived one using Ranges 7 . The contours were entirely congruent, therefore justifying the applied smoothing factor.

\section{Determinants of Home Range Size}

Home range size was predicted using three habitat factors (habitat richness, area of large wood deposits, home range temperature), two biotic factors (prey density, competition), and three individual factors (body mass, sex, animal identification [identity]; tables 1, B1). By applying a principal component analysis, we a priori omitted additional explaining factors reflecting habitat structure because of redundancy or the lack of additional variance explained (table B2). Home range temperature was quantified using 
Table 1: Habitat, biotic, and individual factors used for predicting home range size

\begin{tabular}{|c|c|}
\hline Code & Factor \\
\hline \multicolumn{2}{|c|}{ Habitat factors: } \\
\hline $\mathrm{T}$ & Home range temperature $\left({ }^{\circ} \mathrm{C}\right)$ \\
\hline $\mathrm{Ri}$ & Habitat richness ${ }^{\mathrm{a}}$ \\
\hline Wood & Area of large wood deposits ${ }^{\mathrm{a}, \mathrm{b}}$ \\
\hline \multicolumn{2}{|c|}{ Biotic factors: } \\
\hline Co & Intra- and interspecific competition (m) \\
\hline Prey & Prey density \\
\hline \multicolumn{2}{|c|}{ Individual factors: } \\
\hline M & $\begin{array}{l}\text { Body mass of animals at the beginning of } \\
\text { the tracking period }\end{array}$ \\
\hline Sex & Sex (integer) \\
\hline A & Animal identity (integer) \\
\hline
\end{tabular}

Note: All factors were standardized before analysis.

a Habitat richness and the area of large wood deposits were surrogates for habitat structure. Highly structured habitats were considered to provide more refuges for protection from harmful environmental conditions than would weakly structured habitats.

b Large wood deposits was the preferred habitat type within home ranges (see analysis of habitat selection, table B1 in the online edition of the American Naturalist).

temperature loggers (Thermochron iButton DS1921G, $0.5^{\circ} \mathrm{C}$ resolution). We employed 67 loggers in 2005 and 57 loggers in 2006 and used an hourly logging interval to record temperatures at the sediment surface, with locations distributed in proportion to the aerial cover of individual habitat types. Average home range temperature within a home range was calculated as the area-weighted mean of all habitat types within a specific home range.

Prey density was quantified in 2006 by setting up 100 pitfall traps (diameter $9 \mathrm{~cm}$, depth $12 \mathrm{~cm}$, volume 0.5 L) randomly along three transects perpendicular to the river corridor. The pitfall traps were opened (set) at twilight (8:00-9:30 p.m.) and closed at sunrise (5:00-7:00 a.m.), and the traps were sampled three times (July 2122 , August $8-9$, September 7-8). Average prey availability (number of prey items $\mathrm{m}^{-2}$ ) within the active tract of the floodplain was calculated by applying the inverse distance-weighted interpolation method in ArcGIS 9.0 using log-transformed prey densities (fit of interpolation: $R^{2}=0.466$ ). Competition (intra- and interspecific) was calculated by buffering the kernel center of a home range with a diameter of $19 \mathrm{~m}$ (average $50 \%$ core area) or 45 $\mathrm{m}$ (average 95\% home range) and summing the weighted inverse distances to all other kernel centers within the buffer. The buffer distance was chosen to allow for home range overlap between individuals.

\section{Statistical Analysis}

Modeling strategy. We used an information-theoretic approach (model selection) proposed by Burnham and An- derson (2002) and path analysis (Mitchell 1993) to quantify variation in home range size. The information-theoretic approach was used to fit a set of 11 candidate models from which we derived model-averaged effect sizes to evaluate the importance of explaining factors. Each of these models reflects a hypothesis with a sound basis in the literature (table B3). In contrast to the information-theoretic approach, path analysis is helpful in quantifying both the direct effects of factors on a response variable and their indirect effects on a response variable via intermediary factors. Hence, we quantified the indirect and direct effects of the most important home range size determinants out of the information-theoretic approach, using path analysis to better understand the interrelatedness of factors. The information-theoretic approach therefore served to set the theoretical background for the path models. To avoid redundancy, we focus on the path analysis and refer to appendixes for methods and results out of the informationtheoretic approach (tables B4-B6). We assumed that the interior $50 \%$ core areas were used mainly for resting, while the peripheral areas of the $95 \%$ home range were used mainly for foraging. For modeling, we therefore removed the $50 \%$ core area from the $95 \%$ home range to avoid confounded results.

Path analysis. We fitted path models (AMOS 7.0, SPSS, Chicago) separately per species and spatial scale $(50 \%$ core area, 95\% home range). The direct effects were measured by the standardized partial regression coefficient between $Y$ and $X_{j}$ by holding all other factors constant. The direct effects were the path coefficients relating $Y$ to $X_{j}$. This way, the path models controlled for nuisance correlations among factors typical in field studies. In this study, we accepted a priori the correlation between habitat richness, area of large wood deposits, home range temperature, and prey density (table B7) because each factor may have its own merit. For modeling, we used data from 2006 because prey density was not sampled in 2005. All factors were $z$ standardized before analysis. Home range size was log transformed to assure normally distributed residuals. One outlier (Cook's distance >1) was removed.

\section{Results}

Home range use. The percentage of locations where toads were observed moving ( $=$ foraging) was consistently lower within the $50 \%$ core areas than within the $95 \%$ home ranges (number of locations as percent of total locations in 50\% core areas $/ 95 \%$ home ranges: Bufo bufo spinosus, 5.4/17.2; Bufo viridis, 9.3/40.2; table B8). However, the percentage of total locations animals were seen moving during the day was higher in the $50 \%$ core areas of $B . b$. spinosus than in those of $B$. viridis. These results indicate that the interior core areas were used primarily for resting 
and that the peripheral areas of the $95 \%$ home range were used mainly for foraging but also that $B$. $b$. spinosus may forage to some extent in $50 \%$ core areas. However, our data do not allow further behavioral detail, such as commuting movements between resting and foraging areas, to be resolved.

\section{Home Range Size, Shape, and Overlap}

The mean $50 \%$ core area and $95 \%$ home ranges of B. $b$. spinosus were 48 and $570 \mathrm{~m}^{2}$, respectively, and those of $B$. viridis were 295 and $2,456 \mathrm{~m}^{2}$, respectively (table 2). The differences between the two species were statistically significant $(50 \%$ core areas, univariate ANOVA: $F=9.054$, $\mathrm{df}=1,109, P=.003$, mean squared error $[\mathrm{MSE}]=$ 0.46; 95\% home ranges, univariate ANOVA: $F=10.23$, $\mathrm{df}=1,109, \quad P=.002, \quad$ MSE $=0.433)$. Median home range size was consistently smaller than mean home range size (right-skewed distribution), hence few individuals had very large home ranges (table 2).

The $50 \%$ core areas were not significantly different between sexes $(F=0.186, \mathrm{df}=1,109, P=.667, \mathrm{MSE}=$ $0.46)$, and there was no interaction between species and sexes $(F=0.180, \mathrm{df}=1,109, P=.672, \mathrm{MSE}=0.46)$. Similarly, the $95 \%$ home ranges were not significantly different between sexes $(F=1.713, \mathrm{df}=1,109, P=.193$, MSE $=0.433)$, and there was no interaction between species and sexes $(F=1.694, \quad \mathrm{df}=1,109, \quad P=.196$, MSE $=0.433$.

For each species, virtually all 95\% home ranges were multinuclear; that is, they consisted of spatially separated areas (inset, fig. 1). The relative (\%) overlap of home ranges between species was small (mean \pm SD: $50 \%$ core areas, $0.33 \% \pm 0.20 \% ; 95 \%$ home range, $2.67 \% \pm 1.81 \%$ ), as was the relative overlap of home ranges among individuals of a species (50\% core area: B. b. spinosus, $0.34 \% \pm 0.39 \%$,
B. viridis, $3.10 \% \pm 2.86 \%$; $95 \%$ home range, B. b. spinosus, $2.75 \% \pm 1.88 \%$, B. viridis, $11.24 \% \pm 6.18 \%$ ).

\section{Determinants of Home Range Size}

The most important home range size determinants out of the information-theoretic approach were habitat richness, area of large wood deposits, and prey density (confidence intervals of regression coefficients did not include 0 ), all related to home range temperature (tables B4-B6). Individual factors and the biotic factor competition (table 1) were considered unimportant (confidence intervals included 0; see tables B5, B6). Hence, we used all habitat factors (habitat richness, area of large wood deposits, home range temperature) and the biotic factor prey density to establish a path model, integrating the interrelatedness of factors, to explain variation in home range size (fig. 2). Via the direct path, we predicted that all habitat factors (habitat richness, area of large wood deposits, temperature) and the biotic factor prey density per se may affect home range size. Via the indirect path, we predicted that habitat richness and the area of large wood deposits alter habitat temperature and, therefore, prey density, which in turn might indirectly affect home range size. Factors reflecting habitat structure (habitat richness, area of large wood deposits) explained most variation in log-home range size followed by prey density and temperature (table 3).

Both direct and indirect effects controlled log-home range size of both species (fig. 2). The 50\% core areas and $95 \%$ home ranges of both species increased with the direct effect prey density (table 3; fig. 2). The direct effect of habitat richness was positively related to home range size, except for the $95 \%$ home range of B. b. spinosus. Home range size decreased with the area of large wood deposits and temperature, except for the $50 \%$ core area of $B$. viridis.

Table 2: Home range size estimates and body mass (mean \pm SD) for both toad species

\begin{tabular}{|c|c|c|c|c|c|c|c|c|c|c|c|c|}
\hline \multirow[b]{2}{*}{ Species, year } & \multirow[b]{2}{*}{ Sex } & \multirow[b]{2}{*}{$n$} & \multicolumn{4}{|c|}{$50 \%$ core area $\left(\mathrm{m}^{2}\right)$} & \multicolumn{4}{|c|}{$95 \%$ home range $\left(\mathrm{m}^{2}\right)$} & \multicolumn{2}{|c|}{ Body mass (g) } \\
\hline & & & Median & Mean & SD & Range & Median & Mean & SD & Range & Mean & SD \\
\hline \multicolumn{13}{|c|}{ Bufo bufo spinosus: } \\
\hline 2005 & $\mathrm{M}+\mathrm{F}$ & 25 & 44 & 70 & 104 & $3-406$ & 305 & 675 & 986 & $32-3,620$ & 123.4 & 51.9 \\
\hline 2006 & $\mathrm{M}+\mathrm{F}$ & 29 & 19 & 29 & 37 & $3-191$ & 160 & 480 & 766 & $6-3,345$ & 126.7 & 50.0 \\
\hline $2005 / 2006$ & M & 11 & 26 & 37 & 32 & $3-104$ & 533 & 1,164 & 1,354 & $32-3,620$ & 52.0 & 13.3 \\
\hline $2005 / 2006$ & $\mathrm{~F}$ & 43 & 24 & 51 & 86 & $3-406$ & 210 & 418 & 638 & $6-3,526$ & 143.3 & 38.1 \\
\hline $2005 / 2006$ & $\mathrm{M}+\mathrm{F}$ & 54 & 24 & 48 & 78 & $3-406$ & 230 & 570 & 872 & $6-3,620$ & 125.1 & 50.5 \\
\hline \multicolumn{13}{|l|}{ Bufo viridis: } \\
\hline 2005 & $\mathrm{M}+\mathrm{F}$ & 23 & 95 & 124 & 130 & $4-568$ & 820 & 1,074 & 992 & $36-3,899$ & 30.8 & 5.8 \\
\hline 2006 & $\mathrm{M}+\mathrm{F}$ & 36 & 86 & 404 & 1,016 & $1-5,000$ & 1,472 & 3,339 & 4,810 & $27-17,248$ & 28.0 & 4.6 \\
\hline $2005 / 2006$ & M & 20 & 84 & 466 & 1,126 & $1-5,000$ & 1,337 & 3,028 & 4,470 & $36-13,781$ & 26.6 & 3.4 \\
\hline $2005 / 2006$ & $\mathrm{~F}$ & 39 & 91 & 208 & 578 & $1-3,633$ & 1,109 & 2,162 & 3,677 & $27-17,248$ & 30.5 & 5.6 \\
\hline $2005 / 2006$ & $\mathrm{M}+\mathrm{F}$ & 59 & 91 & 295 & 806 & $1-5,000$ & 1,204 & 2,456 & 3,946 & $27-17,248$ & 29.1 & 5.3 \\
\hline
\end{tabular}

Note: $\mathrm{M}=$ males, $\mathrm{F}=$ females, $\mathrm{n}=$ number of animals. 


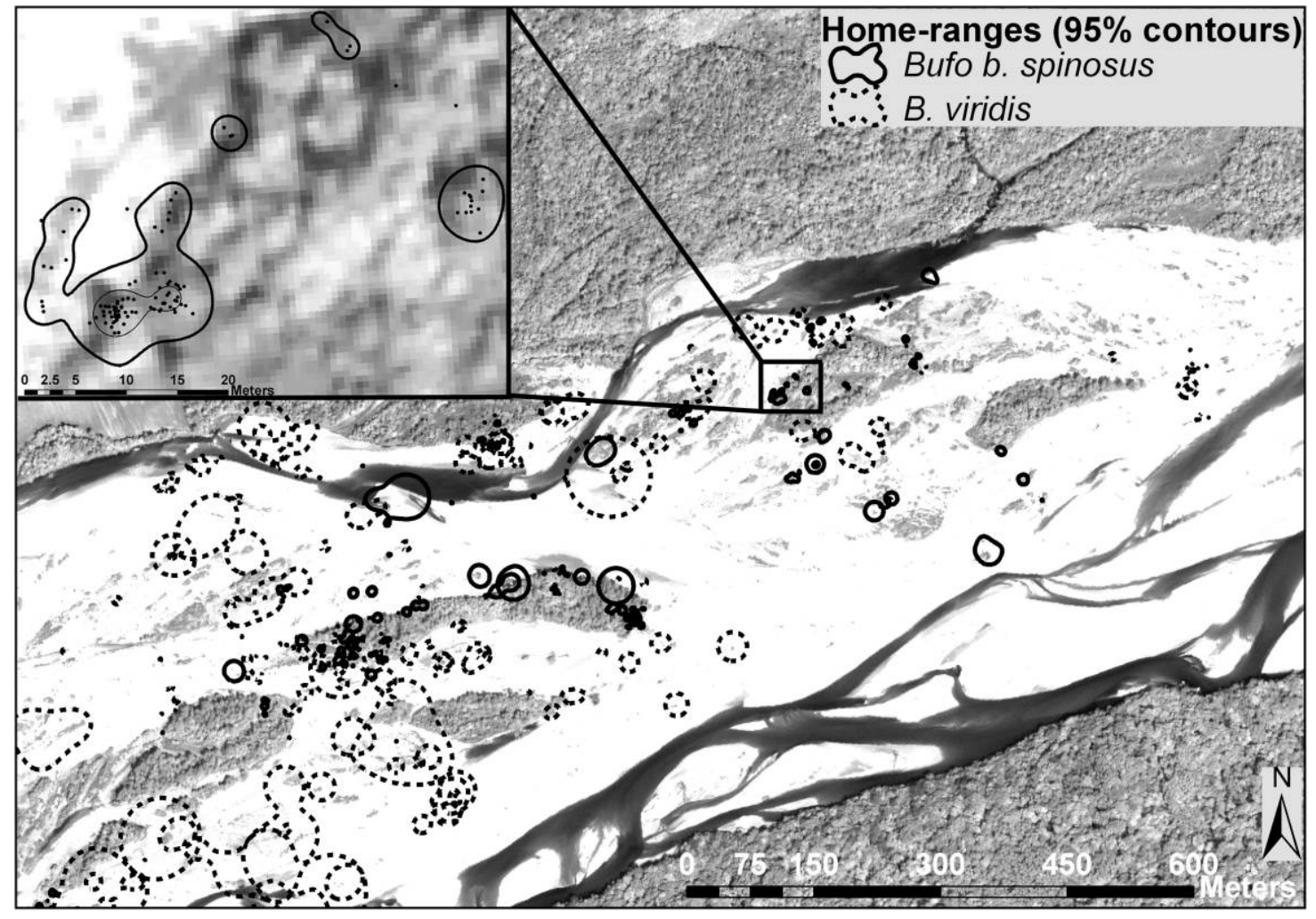

Figure 1: Part of the distribution of home ranges (95\% contours) of both species in the study site (2006 data). Riparian forest fringes the active tract, which is mainly composed of exposed gravel sediments (white), the river network (dark gray), and vegetated islands (pale gray). The inset shows the multinuclear structure of one Bufo bufo spinosus home range $(50 \%$ core area $=$ thin line; $95 \%$ home range $=$ thick line $)$ and the distribution of locations.

Temperature decreased with home range size, except for the $50 \%$ core area of B. b. spinosus.

For B. b. spinosus, habitat richness and the area of large wood deposits had a significant effect on prey density, while for B. viridis, only the area of large wood deposits had a significant effect on prey density (fig. 2). Prey density increased with increasing habitat structure and temperature, except for the $95 \%$ home range of B. viridis, where prey density was inversely related to temperature.

In the $95 \%$ home ranges, prey density and the area of large wood deposits varied less for $B . b$. spinosus than they did for B. viridis (fig. 3). Average prey density in densely vegetated habitats (established islands, dense pioneer vegetation), mainly occupied by B. b. spinsous (fig. 1), was about twice as high (359 individuals $\mathrm{m}^{-2}$ day $^{-1}$ vs. 183 individuals $\mathrm{m}^{-2}$ day $^{-1}$ ) as in open habitats (exposed gravel sediments) that were mainly occupied by $B$. viridis.

Prey availability was dominated by ground-dwelling insects (percent insect density for densely vegetated habitats/ exposed gravel sediments: Coleoptera, 38.4/24.3; Arachnidae, 21.5/38.2; Acarina, 8.8/0; Collembola, 7.0/7.7), while exclusively flying insects (Hymenoptera, 7.4/7.2) contributed marginally to total density.

\section{Hypothesis 1: Habitat Factors Control the Size of 50\% Core Areas}

For B. b. spinosus, the significant direct effects of both habitat factors (area of large wood deposits, temperature) and the biotic factor prey density determined its $50 \%$ core area (fig. $2 A$ ), thereby partly supporting our hypothesis. The size of the $50 \%$ core area decreased with increasing area of large wood deposits (fig. 2A). The biotic factor prey density had the strongest direct effect on the size of $50 \%$ core areas.

For B. viridis, the direct effect of the habitat factor area of large wood deposits controlled its 50\% core area (fig. $2 C$ ), which is in line with our hypothesis. Other biotic, habitat, and individual factors were considered unimportant (tables 3, B5; confidence intervals include 0). Unexpectedly, the size of the $50 \%$ core area increased with increasing area of large wood deposits. 
A) B. b. spinosus, $50 \%$ core area

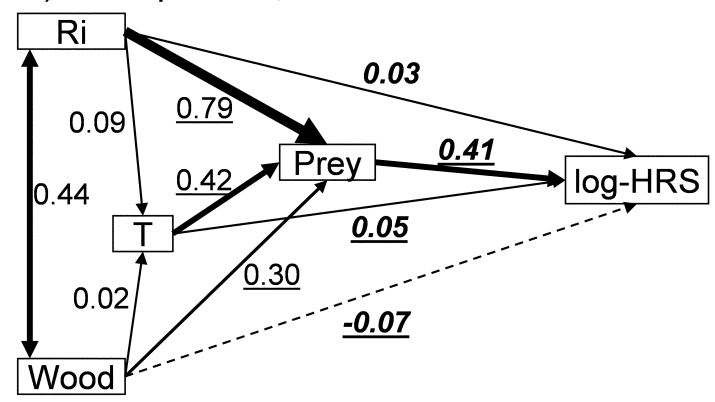

C) B. viridis, $50 \%$ core area

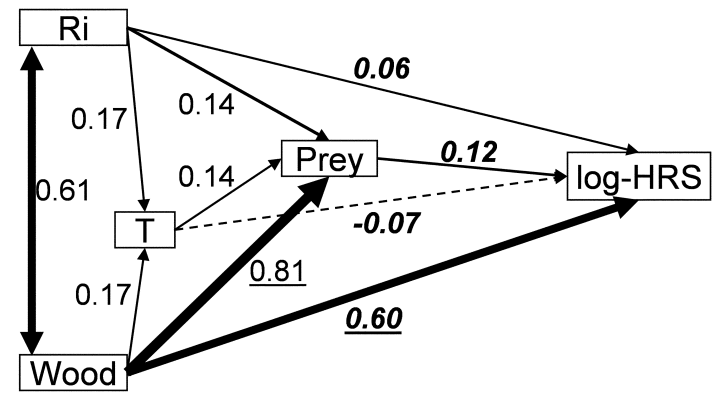

B) B. b. spinosus, $95 \%$ home-range

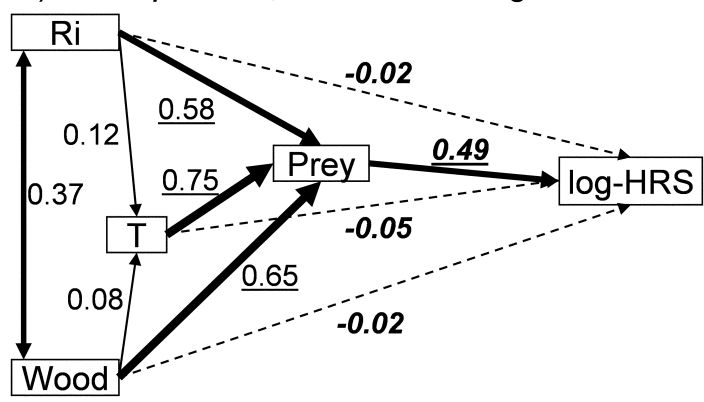

D) B. viridis, $95 \%$ home-range

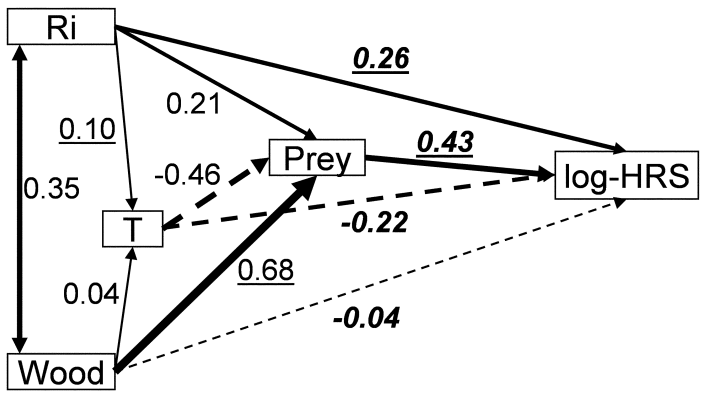

Figure 2: Path diagrams relating the factors habitat richness (Ri), area of large wood deposits ( Wood), home range temperature $(T)$, and prey density (Prey) to log-home range size $(\log$-HRS), separately per species, $50 \%$ core area, and $95 \%$ home range. The values for standardized direct effects (bold text) and indirect effects (plain text) are given adjacent to the arrows. The thickness of arrows is proportional to the effect size of factors. Significant effects are underlined (see table 3 for significance levels). Negative relationships are shown with broken lines. Single-headed arrows represent causal effects; double-headed arrows represent correlations.

\section{Hypothesis 2: Biotic Factors Control the Size of 95\% Home Ranges}

For B. b. spinosus, the biotic factor prey density solely determined its $95 \%$ home range (fig. $2 B$ ). Hypothesis 2 was partly supported, because the biotic factor competition poorly explained variation in its $95 \%$ home range and the size of the $95 \%$ home range increased with increasing prey density (table 3; fig. 2B).

For $B$. viridis, the direct effects of the factors habitat richness and prey density controlled the size of its $95 \%$ home range, thereby partly constituting our hypothesis (table 3; fig. 2D). The $95 \%$ home ranges were largest when both habitat richness and prey density were high.

\section{Hypothesis 3: The Effects of Individual Factors Are Outweighed by the Effects of Habitat and Biotic Factors}

All individual factors were poorly supported, as indicated by the results of the information-theoretic approach, thereby confirming our hypothesis (tables B4, B5). Sampling bias, expressed by either the number of locations collected (table B5) or the number of weeks that toads were tracked (table B6), poorly explained variation in home range size (confidence intervals included 0 ). The direct effect sizes evaluated using path analysis (table 3; fig. 2) were similar to those evaluated with the information-theoretic approach (table B5).

\section{Discussion}

Our main goal was to quantify the separate direct and indirect effects of habitat, biotic, and individual factors on summer home range size of amphibians (Bufo bufo spinosus and Bufo viridis) at biologically relevant spatial scales, namely, $50 \%$ core areas that are the interior areas of home ranges with the highest intensity of use and 95\% home ranges that include large peripheral areas (about 10 times the size of $50 \%$ core areas). We hypothesized (hypothesis 1) that the $50 \%$ core areas are mainly used for resting and therefore controlled by habitat factors reflecting refuge density (habitat richness, area of large wood deposits), while (hypothesis 2) the 95\% home ranges (excluding the $50 \%$ core areas) are used for foraging and therefore are 
Table 3: Effect sizes $(\beta)$ and variances $\left(R^{2}\right)$ with standard errors for the path models (see fig. 2)

\begin{tabular}{|c|c|c|c|c|c|c|c|c|c|c|}
\hline \multirow[b]{2}{*}{ Factors } & \multicolumn{5}{|c|}{$50 \%$ core area } & \multicolumn{5}{|c|}{$95 \%$ home range } \\
\hline & $\beta$ & SE & $P$ & $R^{2}$ & SE & $\beta$ & SE & $P$ & $R^{2}$ & SE \\
\hline \multicolumn{6}{|c|}{$\begin{array}{l}\text { Bufo bufo spinosus }(n=23 \text {, GFI }=.345) \text { : } \\
\text { Direct effects: }\end{array}$} & \multicolumn{5}{|c|}{$\begin{array}{l}\text { Bufo b. spinosus }(n=22 \text {, GFI }=.356) \text { : } \\
\text { Direct effects: }\end{array}$} \\
\hline $\mathrm{Ri}$ & .030 & .017 & .078 & .762 & .023 & -.018 & .027 & .501 & .754 & .233 \\
\hline Wood & -.074 & .110 & $<.001$ & .523 & .158 & -.017 & .035 & .634 & .406 & .125 \\
\hline $\mathrm{T}$ & .052 & .017 & .002 & .114 & .034 & -.045 & .041 & .269 & .160 & .049 \\
\hline Prey & .409 & .014 & $<.001$ & .071 & .021 & .493 & .028 & $<.001$ & .255 & .079 \\
\hline e3 & & & & .001 & & & & & .004 & .001 \\
\hline \multicolumn{6}{|l|}{ Indirect effects: } & \multicolumn{3}{|c|}{ Indirect effects: } & & \\
\hline $\mathrm{Ri} \rightarrow \mathrm{T}$ & .087 & .115 & .452 & & & .119 & .135 & .379 & & \\
\hline $\mathrm{Ri} \rightarrow$ prey & .788 & .092 & $<.001$ & & & .577 & .174 & $<.001$ & & \\
\hline Wood $\rightarrow \mathrm{T}$ & .020 & .139 & .883 & & & .079 & .184 & .667 & & \\
\hline Wood $\rightarrow$ prey & .301 & .110 & .006 & & & .646 & .234 & .006 & & \\
\hline $\mathrm{T} \rightarrow$ prey & .421 & .168 & .012 & & & .754 & .275 & .006 & & \\
\hline \multicolumn{6}{|c|}{$\begin{array}{l}\text { Bufo viridis }(n=24, \mathrm{GFI}=.318) \text { : } \\
\text { Direct effects: }\end{array}$} & \multicolumn{5}{|c|}{$\begin{array}{l}\text { B. viridis }(n=28 \text {, GFI }=.489) \text { : } \\
\text { Direct effects: }\end{array}$} \\
\hline $\mathrm{Ri}$ & .057 & .067 & .393 & .990 & .292 & .258 & .076 & $<.001$ & .905 & .242 \\
\hline Wood & .597 & .103 & $<.001$ & .788 & .233 & -.042 & .093 & .648 & .828 & .221 \\
\hline $\mathrm{T}$ & -.073 & .144 & .614 & .094 & .028 & -.217 & .295 & .462 & .042 & .011 \\
\hline Prey & .123 & .091 & .176 & .235 & .069 & .435 & .085 & $<.001$ & .489 & .131 \\
\hline e3 & & & & .045 & .013 & & & & .099 & .027 \\
\hline \multicolumn{6}{|l|}{ Indirect effects: } & \multicolumn{3}{|c|}{ Indirect effects: } & & \\
\hline $\mathrm{Ri} \rightarrow \mathrm{T}$ & .088 & 1.925 & .054 & & & .100 & .044 & .024 & & \\
\hline $\mathrm{Ri} \rightarrow$ prey & .151 & .946 & .344 & & & .206 & .165 & .211 & & \\
\hline Wood $\rightarrow \mathrm{T}$ & .099 & 1.723 & .085 & & & .039 & .046 & .395 & & \\
\hline Wood $\rightarrow$ prey & .167 & 4.853 & $<.001$ & & & .682 & .161 & $<.001$ & & \\
\hline $\mathrm{T} \rightarrow$ prey & .331 & .438 & .661 & & & -.462 & .648 & .476 & & \\
\hline
\end{tabular}

Note: See table 1 for abbreviations of factors. All factors were standardized before analysis. $P=P$ value for significance level .001 , e $3=$ unexplained variance in log-home range size, and GFI = goodness-of-fit index for the most constrained model. Values $<0$ and $>1$ indicate that the data do not fit the model, while values close to 1 indicate good fit (Jöreskog and Sörbom 1984). The true model fit here lies somewhere between the reported GFI values and 1.

controlled by biotic factors (prey density, competition). Furthermore (hypothesis 3 ), the impacts of individual factors on $50 \%$ core areas and $95 \%$ home ranges were hypothesized to be marginal compared to habitat and biotic factors.

Our results demonstrate that a web of habitat and biotic factors determines summer home range size of both species. However, the two species responded differently to the same web of factors when using 50\% core areas and 95\% home ranges.

\section{The Impact of Direct and Indirect Effects of Habitat and Biotic Factors on Space Use}

Direct effects. Our results demonstrate that the sizes of the $50 \%$ core areas and $95 \%$ home ranges of two amphibian species, differing in life history and ecology, were primarily governed by habitat structure (habitat richness, area of large wood deposits) and prey density (food resources; table 3; fig. 2). However, the generalist species B. b. spinosus responded to the area of large wood deposits and prey density within its $50 \%$ core area (table 3 ; fig. $2 A$ ), while the pioneer species $B$. viridis solely responded to the area of large wood deposits (table 3; fig. 2C). These results suggest that $B . b$. spinosus may rest and forage within $50 \%$ core areas while $B$. viridis rests only within core areas, in line with behavioral field data (table B8). Furthermore, these results demonstrate the dominating effect of single habitat structures on space use, which has been shown for other animals, such as birds (Pasinelli 2000; Buner et al. 2005) and bears (McLoughlin et al. 2003).

For both species, the $50 \%$ core areas increased with increasing habitat structure (surrogate for refuge density), except for B. b. spinosus, where the $50 \%$ core area decreased with increasing areas of large wood deposits (fig. $2 A, 2 C$ ). Hence, individuals may increase their core areas to include multiple habitat types (B. b. spinosus; table B5) or large wood deposits (B. b. spinosus, B. viridis) that are patchily distributed. A similar relationship was found by Tufto et al. (1996) and Rosalino et al. (2004) for roe deer and badgers. These results are in line with the resource-dispersion hypothesis (Macdonald 1983), which predicts that 

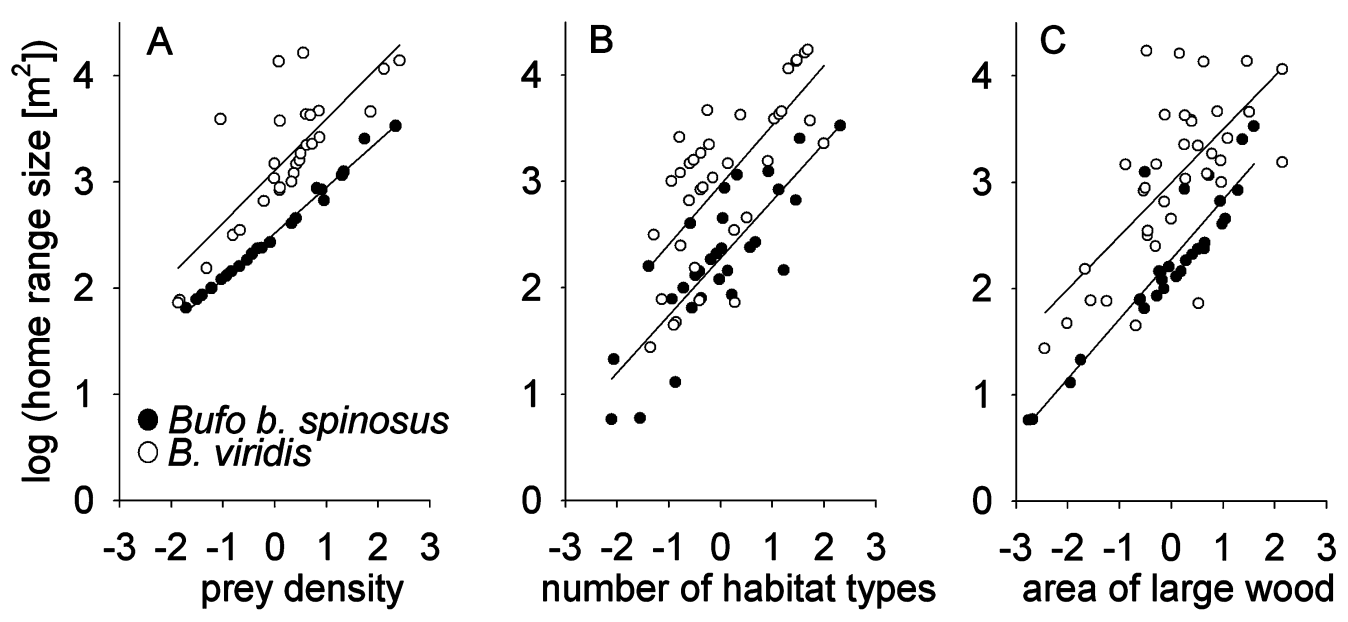

Figure 3: Relationships between log-home range size (95\% home range) and prey density $(A)$, number of habitat types (habitat richness; $B)$, and area of large wood deposits $(C)$. Standardized values are shown. The relationships in figure 3 deviate partly from those in figure 2 due to the exclusion of other explaining factors and their interrelatedness.

home range size increases when resources are patchily distributed. Hypothesis 1 was partly supported because both habitat and biotic factors determined the size of the $50 \%$ core areas of $B . b$. spinosus.

The $95 \%$ home range of $B$. $b$. spinosus was solely determined by the biotic factor prey density, which implies that this species forages in the peripheral areas of its home range (table 3; fig. $2 B$ ). For $B$. viridis, habitat richness and prey density controlled the size of its $95 \%$ home range (table 3; fig. 2D). Bufo viridis may therefore forage in more diverse habitats because of their higher productivity and/ or because predatory shelters are located close to foraging areas in exposed gravel sediments. For example, rodents and ungulates reduced predation risk by decreasing distances between foraging places and shelters (Lagos et al. 1995; Hamel and Cote 2007). The patchy distribution of predatory shelters and prey as well as the depletion of food patches may have forced toads to extend their foraging areas, thereby increasing $95 \%$ home ranges. The resulting multinuclear home range structure (inset, fig. 1) is most likely a general phenomenon in pond-breeding amphibians (Semlitsch 1981; Forester et al. 2006). In addition, large home ranges are considered to mitigate the impacts of fluctuating environmental conditions (Ferguson et al. 1999), which are characteristic of dynamic floodplains (Arscott et al. 2001; Naiman et al. 2005). In contrast, small home ranges (table 2) might have resulted from the occasional spatial aggregation of food resources and refuge. Toads may stop adding areas to their home ranges when minimum requirements are met. Therefore, increasing home range size does not necessarily result in higher prey and refuge density.
The generalist species B. b. spinosus occupied densely vegetated habitats where prey density was about twice as high as in habitats mainly occupied by the pioneer species B. viridis (fig. 1). The habitats of both species differed little in prey composition, implying rather indiscriminate feeding habits of the two toads. Indeed, a number of studies showed prey selection by amphibians to depend on prey availability rather than prey size (Smith and Bragg 1949; Berry 1970). In addition, individuals of the same amphibian species that differed largely in body size selected prey items of all sizes (Inger 1969). Hence, B. viridis might have increased its $95 \%$ home range much more than $B$. b. spinosus to compensate for low prey density. This may explain the large differences in home range size among species (table 2) and suggests pioneer species may be more limited by prey density than generalist species.

Hypothesis 2 was partly supported, as the $95 \%$ home range of B. viridis was determined by both prey density and habitat richness. However, competition was a poor predictor, although juveniles and undetected adults were excluded from our studies. Nevertheless, we consider our results robust. First, competition is most likely low under harsh environmental conditions (intermediate disturbance hypothesis; Connell 1979). Second, we radio-tracked a representative sample of the reproductive population (about $30 \%$ of B. b. spinosus and $60 \%$ of B. viridis), an estimate that is based on all individuals that were ever caught (app. B) on egg clutch counts over 2 years (L. Indermaur, unpublished data) and by assuming equal sex ratios.

Indirect effects. Prey density increased with increasing habitat structure (habitat richness, area of large wood deposits) and mostly with increasing temperature (fig. 2). 
However, prey availability for the generalist species $B . b$. spinosus was determined by overall habitat structure (habitat richness, area of large wood deposits), while prey availability for the pioneer species was determined by a single habitat structure (area of large wood deposits). Hence, both species used highly structured habitats because of their expected high productivity, as well as of their role as potential thermal and predatory refugia.

In general, home range size decreased with increasing temperature, except for the $50 \%$ core area of B. b. spinosus, where home ranges were largest when temperature was high (fig. 2). Bufo b. spinosus was exposed to moderate temperature in densely vegetated habitats (maximum $33.5^{\circ} \mathrm{C}$ ), whereas $B$. viridis was exposed to highest temperature in open habitats (maximum $43^{\circ} \mathrm{C}$ ). Hence, at high temperature, $B$. $b$. spinosus may move and therefore may forage more actively in its $50 \%$ core area (table B8). For $B$. viridis, which mainly rests in large wood deposits (mean maximum $27.2^{\circ} \mathrm{C}$ ), leaving thermal shelter may increase the desiccation risk, thereby decreasing movement activity and home range size.

\section{The Impact of Individual Factors on Space Use}

As expected (hypothesis 3), individual factors poorly explained variation in 50\% core areas and 95\% home ranges (tables B4-B6). The weak impact of body mass on $50 \%$ core areas and 95\% home ranges is in accordance with previous studies on deer (Relyea et al. 2000; Said and Servanty 2005) and bears (Dahle and Swenson 2003). We argue that in the amphibian body, mass strongly fluctuates due to evaporation and hydration, thereby masking changes in body fat. Furthermore, in patchy environments such as dynamic floodplains, metabolic requirements may not depend linearly on home range size. Differences among individuals, expressed by the animal identity factor, were far less important than habitat and biotic factors (tables B4-B6), in contradiction to experimental data on Tribolium beetles that were kept in microlandscapes of varying complexity but stable environmental conditions (Morales and Ellner 2002). We expect that differences among individuals might be more important in less variable environments (Klopfer and MacArthur 1960).

\section{Conclusions}

We demonstrated that the summer home range size $(50 \%$ core areas and 95\% home ranges) of two pond-breeding amphibians was a function of prey density and habitat structure (habitat richness, area of large wood deposits). Habitat factors affected home range size directly, probably by increasing refuge density, or indirectly, by increasing prey availability. This finding implies that the terrestrial area requirements of amphibians depend on the productivity and spatiotemporal complexity of the landscape. Reducing habitat complexity may therefore impede resting and foraging behaviors, which are both paramount for survival and future reproduction (Wälti and Reyer 2007). The relative importance of the same factors varied between species and across spatial scales (50\% core areas, 95\% home ranges). Therefore, differential space use facilitates the coexistence of the two toad species in the terrestrial summer habitat.

Our results did not fully correspond with the assumption that $50 \%$ core areas mainly integrate resting behavior, because for B. b. spinosus, the habitat factor area of large wood deposits (surrogate for refuge) and the biotic factor prey density determined the $50 \%$ core area. This suggests that resting and foraging behaviors may not be spatially separated. The use of behavior-related scale definitions therefore contributes to our understanding of spatially structured populations, regardless of whether underlying assumptions are met. Behavior-based scale definitions, applying an information-theoretic approach, and path analysis provide a promising framework to disentangle the web of factors governing space use and hence advance home range studies.

Further research should focus on the relationships between habitat structure, resource density, and population dynamics. A number of empirical studies have shown that home range size depends on habitat structure and/or resource density (Ebersole 1980; Prohl and Berke 2001; Buner et al. 2005; our study). Home range size is generally predicted to decrease when population density increases (Kjellander et al. 2004; Wang and Grimm 2007). However, we lack empirical evidence that home range size and population dynamics are similarly controlled by the interplay of habitat structure and resource density. Approaching this topic would require an experimental setup where levels of habitat structure and resource density are easily manipulated and the response (home range size, population density) can be quantified. Another research direction should focus on the effect of qualitative differences (physiological state, tolerance to environmental factors) among individuals on home range size in relation to environmental stability. As previously argued, theory predicts individual differences to be more important in stable rather than in dynamic environments (Klopfer and MacArthur 1960). As dynamic floodplains become more and more regulated and, therefore, habitat stability increases, differences among individuals might become more important in controlling home range size. Furthermore, if there is evidence for individual differences, it is important to determine whether these are related to survival and passed on to offspring. 


\section{Acknowledgments}

We are grateful to T. Winzeler for collecting field data. We especially thank L. Börger, J. Jokela, M. Mitchell, K. Räsänen, B. Schmidt, and two anonymous reviewers for their insightful comments and criticism that improved the manuscript. Thanks to M. Harner and W. Nelson for polishing our language. We would like to thank the national authorities (Ministerio dell'Ambiente e della Tutela del Territorio, Direzione per la Protezione della Natura, Roma) and the regional authorities (Direzione Centrale Risorse Agricole, Forestali e Naturali, Regione Friuli Venezia Giulia, Udine) in Italy for their kindness in providing permits for radio-tagging animals. The project was supported by the MAVA foundation (Switzerland).

\section{Literature Cited}

Arscott, D. B., K. Tockner, and J. V. Ward. 2001. Thermal heterogeneity along a braided floodplain river (Tagliamento River, northeast Italy). Canadian Journal of Fisheries and Aquatic Sciences 58: 2359-2373.

Arscott, D. B., K. Tockner, D. van der Nat, and J. V. Ward. 2002. Aquatic habitat dynamics along a braided alpine river ecosystem (Tagliamento River, northeast Italy). Ecosystems 5:802-814.

Arthur, S. M., B. F. J. Manly, L. L. McDonald, and G. W. Garner. 1996. Assessing habitat selection when availability changes. Ecology 77:215-227.

Berry, P. Y. 1970. The food of the giant toad Bufo asper. Zoological Journal of the Linnean Society 49:61-68.

Biedermann, R. 2003. Body size and area-incidence relationships: is there a general pattern? Global Ecology and Biogeography 12:381387.

Börger, L., N. Franconi, F. Ferretti, F. Meschi, G. De Michele, A. Gantz, and T. Coulson. 2006b. An integrated approach to identify spatiotemporal and individual-level determinants of animal home range size. American Naturalist 168:471-485.

Buner, F., M. Jenny, N. Zbinden, and B. Naef-Daenzer. 2005. Ecologically enhanced areas: a key habitat structure for re-introduced grey partridges Perdix perdix. Biological Conservation 124:373381.

Burnham, K. P., and D. R. Anderson. 2002. Model selection and multimodel inference: a practical information-theoretic approach. 2nd ed. Springer, New York.

Burt, W. H. 1943. Territoriality and home range concepts as applied to mammals. Journal of Mammalogy 24:346-352.

Clutton-Brock, T. H., F. Guiness, and S. D. Albon. 1982. Red deer: behaviour and ecology of two sexes. University of Chicago Press, Chicago.

Connell, J. H. 1979. Intermediate-disturbance hypothesis. Science 204:1344-1345.

Dahle, B., and J. E. Swenson. 2003. Home ranges in adult Scandinavian brown bears (Ursus arctos): effect of mass, sex, reproductive category, population density and habitat type. Journal of Zoology (London) 260:329-335.

Degani, G., N. Silanikove, and A. Shkolnik. 1984. Adaptation of green toad (Bufo viridis) to terrestrial life by urea accumulation. Comparative Biochemistry and Physiology 77:585-587.

Ebersole, J. P. 1980. Food density and territory size: an alternative model and a test on the reef fish Eupomacentrus leucostictus. American Naturalist 115:492-509.

Ferguson, S. H., M. K. Taylor, E. W. Born, A. Rosing-Asvid, and F. Messier. 1999. Determinants of home range size for polar bears (Ursus maritimus). Ecology Letters 2:311-318.

Forester, D. C., J. W. Snodgrass, K. Marsalek, and Z. Lanham. 2006. Post-breeding dispersal and summer home range of female American toads (Bufo americanus). Northeastern Naturalist 13:59-72.

Giacoma, C., and S. Castellano. 2006. Bufo bufo and Bufo viridis. Pages 302-311 in R. Sindaco, G. Doria, E. Razzetti, and F. Bernini, eds. Atlas of Italian amphibians and reptiles. Societas Herpetologica Italica, Edizione Polistampa, Firenze.

Hamel, S., and S. D. Cote. 2007. Habitat use patterns in relation to escape terrain: are alpine ungulate females trading off better foraging sites for safety? Canadian Journal of Zoology 85:933-943.

Hayne, D. W. 1949. Calculation of size of home range. Journal of Mammalogy 30:1-18.

Hixon, M. A. 1980. Food production and competitor density as determinants of feeding territory size. American Naturalist 115: 510-530.

Hoffman, J., and U. Katz. 1989. The ecological significance of burrowing behavior in the toad (Bufo viridis). Oecologia (Berlin) 81: 510-513.

Indermaur, L., B. R. Schmidt, and K. Tockner. 2008. Effect of transmitter mass and tracking duration on body mass change of two anuran species. Amphibia-Reptilia 29:263-269.

Inger, R. F. 1969. Organization of communities of frogs along small rain forest streams in Sarawak. Journal of Animal Ecology 38:123148 .

Jöreskog, K. G., and D. Sörbom. 1984. Advances in factor analysis and structural equation models. Rowman and Littlefield, Plymouth.

Kenward, R. E. 1985. Ranging behaviour and population dynamics in grey squirrels. Pages 319-330 in R. M. Silbly and R. H. Smith, eds. Behavioral ecology: ecological consequences of adaptive behaviour. Blackwell Scientific, Oxford.

2001. A manual for wildlife radio tagging. Academic Press, San Diego, CA.

Kie, J. G., R. T. Bowyer, M. C. Nicholson, B. B. Boroski, and E. R. Loft. 2002. Landscape heterogeneity at differing scales: effects on spatial distribution of mule deer. Ecology 83:530-544.

Kjellander, P., A. J. M. Hewison, O. Liberg, J. M. Angibault, E. Bideau, and B. Cargnelutti. 2004. Experimental evidence for densitydependence of home range size in roe deer (Capreolus capreolus L.): a comparison of two long-term studies. Oecologia (Berlin) 139:478-485.

Klopfer, P. H., and R. H. MacArthur. 1960. Niche size and faunal diversity. American Naturalist 94:293-300.

Lagos, V. O., L. C. Contreras, P. L. Meserve, J. R. Gutierrez, and F. M. Jaksic. 1995. Effects of predation risk on space use by small mammals: a field experiment with a Neotropical rodent. Oikos 74:259-264.

Lima, S. L., and L. M. Dill. 1990. Behavioural decisions made under the risk of predation: a review and prospectus. Canadian Journal of Zoology 68:619-640.

Lombardi, L., N. Fernandez, and S. Moreno. 2007. Habitat use and spatial behaviour in the European rabbit in three Mediterranean environments. Basic and Applied Ecology 8:453-463.

Lomnicki, A. 1988. Population ecology of individuals. Princeton University Press, Princeton, NJ. 
Macdonald, D. W. 1983. The ecology of carnivore social behaviour. Nature 301:379-384.

Marzluff, J. M., S. T. Knick, and J. J. Millspaugh. 2001. High-tech behavioral ecology: modeling the distribution of animal activities to better understand wildlife space use and resource selection. Pages 309-326 in J. J. Millspaugh and J. M. Marzluff, eds. Radiotracking and animal populations. Academic Press, San Diego, CA.

McLoughlin, P. D., H. D. Cluff, R. J. Gau, R. Mulders, R. L. Case, and F. Messier. 2003. Effect of spatial differences in habitat on home ranges of grizzly bears. Ecoscience 10:11-16.

McNab, B. K. 1963. Bioenergetics and determination of home range size. American Naturalist 97:133-140.

Meek, R., and E. Jolley. 2006. Body temperatures of the common toad, Bufo bufo, in the Vendee, France. Herpetological Bulletin 95: 21-24.

Mitchell, R. J. 1993. Path analysis: pollination. Pages 211-231 in M. S. Scheiner and J. Gurevitch, eds. Design and analysis of ecological experiments. Chapman \& Hall, New York.

Morales, J. M., and S. P. Ellner. 2002. Scaling up animal movements in heterogeneous landscapes: the importance of behavior. Ecology 83:2240-2247.

Naiman, R. J., H. Décamps, and M. E. McClain. 2005. Riparia: ecology, conservation and management of streamside communities. Elsevier Academic, Burlington, MA.

Pasinelli, G. 2000. Oaks (Quercus sp.) and only oaks? relations between habitat structure and home range size of the middle spotted woodpecker (Dendrocopos medius). Biological Conservation 93: 227-235.

Petts, G. E., A. M. Gurnell, A. J. Gerrard, D. M. Hannah, B. Hansford, I. Morrissey, P. J. Edwards, et al. 2000. Longitudinal variations in exposed riverine sediments: a context for the ecology of the Fiume Tagliamento, Italy. Aquatic Conservation: Marine and Freshwater Ecosystems 10:249-266.

Powell, R. A. 2000. Animal home ranges and territories and home range estimators. Pages $65-110$ in L. Boitani and T. K. Fuller, eds. Research techniques in animal ecology: controversies and consequencies. Columbia University Press, New York.

Prohl, H., and O. Berke. 2001. Spatial distributions of male and female strawberry poison frogs and their relation to female reproductive resources. Oecologia (Berlin) 129:534-542.

Rathbun, G. B., and T. G. Murphey. 1996. Evaluation of a radio-belt for ranid frogs. Herpetological Review 27:187-189.

Relyea, R. A., R. K. Lawrence, and S. Demarais. 2000. Home range of desert mule deer: testing the body-size and habitat-productivity hypotheses. Journal of Wildlife Management 64:146-153.

Revilla, E., T. Wiegand, F. Palomares, P. Ferreras, and M. Delibes. 2004. Effects of matrix heterogeneity on animal dispersal: from individual behavior to metapopulation-level parameters. American Naturalist 164:130-153.

Richards, S. J., U. Sinsch, and R. A. Alford. 1994. Radio tracking. Pages $155-157$ in W. R. Heyer, M. A. Donnelly, R. W. McDiarmid, L. C. Hayek, and M.S. Foster, eds. Measuring and monitoring biological diversity: standard methods for amphibians. Smithsonian Institution, Washington, DC.

Rittenhouse, T. A. G., and R. D. Semlitsch. 2007. Distribution of amphibians in terrestrial habitat surrounding wetlands. Wetlands 27:153-161.
Rosalino, L. M., D. W. Macdonald, and M. Santos-Reis. 2004. Spatial structure and land-cover use in a low-density Mediterranean population of Eurasian badgers. Canadian Journal of Zoology 82:14931502.

Said, S., and S. Servanty. 2005. The influence of landscape structure on female roe deer home range size. Landscape Ecology 20:10031012.

Schoener, T. W. 1968. Sizes of feeding territories among birds. Ecology 49:123-141.

Schwarzkopf, L., and R. A. Alford. 1996. Desiccation and shelter-site use in a tropical amphibian: comparing toads with physical models. Functional Ecology 10:193-200.

Seebacher, F., and R. A. Alford. 2002. Shelter microhabitats determine body temperature and dehydration rates of a terrestrial amphibian (Bufo marinus). Journal of Herpetology 36:69-75.

Semlitsch, R. D. 1981. Terrestrial activity and summer home range of the mole salamander (Ambystoma talpoideum). Canadian Journal of Zoology 59:315-322.

Smith, C. C., and A. N. Bragg. 1949. Observations on the ecology and natural history of Anura. VII. Food and feeding habits of the common species of toads in Oklahoma. Ecology 30:333-349.

South, A. B., R. E. Kenward, and S. S. Walls. 2005. Ranges 7 v1: for the analysis of tracking and location data. Online manual. Anatrack, Wareham, UK.

Steury, T. D., and D. L. Murray. 2003. Causes and consequences of individual variation in territory size in the American red squirrel. Oikos 101:147-156.

Tockner, K., J. V. Ward, D. B. Arscott, P. J. Edwards, J. Kollmann, A. M. Gurnell, G. E. Petts, and B. Maiolini. 2003. The Tagliamento River: a model ecosystem of European importance. Aquatic Sciences 65:239-253.

Tockner, K., I. Klaus, C. Baumgartner, and J. V. Ward. 2006. Amphibian diversity and nestedness in a dynamic floodplain river (Tagliamento, NE Italy). Hydrobiologia 565:121-133.

Trenham, P. C., and H. B. Shaffer. 2005. Amphibian upland habitat use and its consequences for population viability. Ecological Applications 15:1158-1168.

Tufto, J., R. Andersen, and J. Linnell. 1996. Habitat use and ecological correlates of home range size in a small cervid: the roe deer. Journal of Animal Ecology 65:715-724.

Wälti, M. O., and H. U. Reyer. 2007. Food supply modifies the tradeoff between past and future reproduction in a sexual parasite-host system (Rana esculenta, Rana lessonae). Oecologia (Berlin) 152: 415-424.

Wang, M., and V. Grimm. 2007. Home range dynamics and population regulation: an individual-based model of the common shrew Sorex ayaneus. Ecological Modelling 205:397-409.

Ward, J. V., K. Tockner, P. J. Edwards, J. Kollmann, G. Bretschko, A. M. Gurnell, G. E. Petts, and B. Rosaro. 1999. A reference river system for the Alps: the "Fiume Tagliamento." Regulated Rivers: Research and Management 15:63-75.

Worton, B. J. 1989. Kernel methods for estimating the utilisation distribution in home range studies. Ecology 70:164-168.

Associate Editor: Thomas N. Sherratt Editor: Monica A. Geber 


\section{Appendix A from L. Indermaur et al., "Behavior-Based Scale}

Definitions for Determining Individual Space Use: Requirements of Two Amphibians"

(Am. Nat., vol. 173, no. 1, p. 60)

\section{Supplemental Figures}

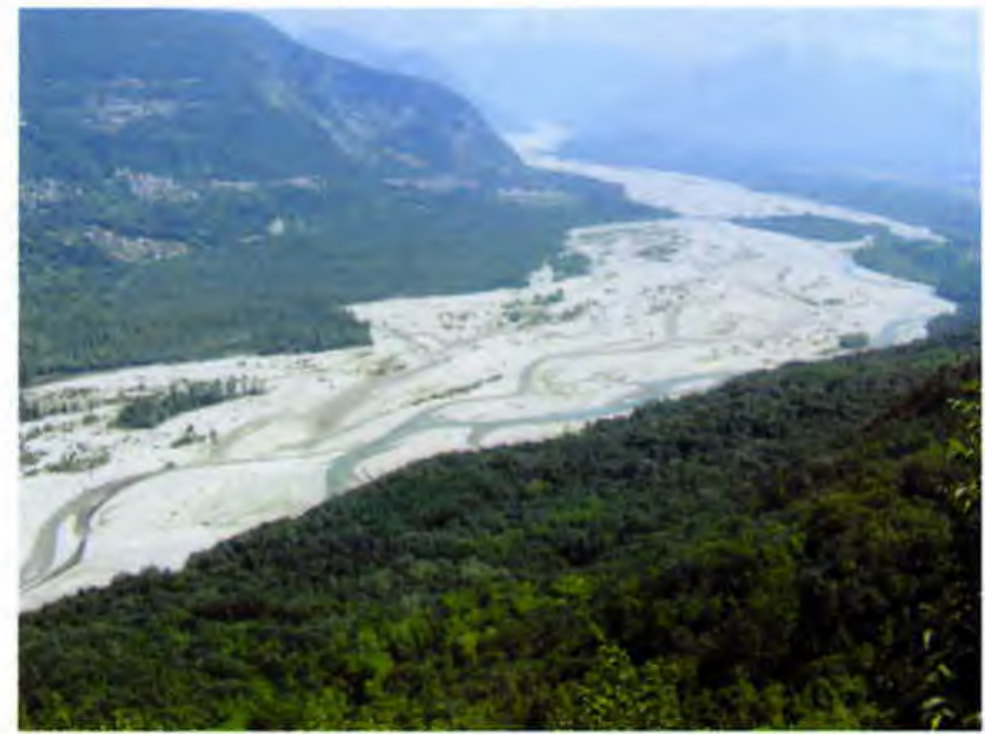

Figure A1: Overview of the study site from Monte Ragogna (Indermaur et al. 2008). 


\section{Appendix B from L. Indermaur et al., "Behavior-Based Scale Definition for Determining Individual Space Use: Requirements of Two Amphibians"}

(Am. Nat., vol. 173, no. 1, p. 60)

\section{Evaluation of Tracking Success and Failure}

We conducted a pilot study in 2004 on 10 individuals of Bufo bufo bufo that were radio-tracked from the end of June until the beginning of September and were located once each day and night to evaluate the performance of transmitters. Adult toads were ftted with radio transmitters LT2-351 (2 g) or LT2-392 (5 g; Titley Electronics, Ballina, Australia). The life spans of transmitters were about 10 weeks and 6 months, respectively. The detection range varied between 10 and $400 \mathrm{~m}$, depending on the terrain topography and the animals' hiding places. When animals were buried underneath stones and fitte with transmitter LT2-351, the detection range was minimal. Signals of transmitters LT2-392 were consistently stronger than signals of transmitter LT2-351.

The transmitters were tightly fitte with an aluminum beaded-chain belt (Ball Chain Manufacturing, Mount Vernon, NY) around the waist (Rathbun and Murphey 1996; fig A2). Animals either accepted the transmitter or tried to get rid of it by moving with outstretched legs. In the latter case, we quickly removed the transmitter. The beaded-chain belt caused lateral abrasions on every second animal during the pilot study. When the abrasions did not heal after loosening the belt, we removed the radio transmitter. In $2 \%$ of the relocations, the antenna was entangled in dense vegetation and animals had to be manually released. The radio transmitters were modifie in this respect for the main study; that is, we attached less flexibl antennas to avoid tangles in dense vegetation.

For the main study in 2005 and 2006 in Italy, the belt was coated with black Plasti Dip (Plasti Dip, Blaine, $\mathrm{MN}$ ), a silicon-like substance, to avoid lateral abrasion and to be more cryptic to predators. Coating the belt clearly prevented abrasions: out of 114 individuals of Bufo bufo spinosus and 134 individuals of Bufo viridis that were ever $\mathrm{ftted}$ with a radio transmitter, 1 individual of B. b. spinosus $(1 \%)$ and 5 individuals of B. viridis $(4 \%)$ had lateral abrasions. We removed the transmitters from these animals and excluded them from analyses. Three individuals of $B$. viridis became snagged on vegetation by the belt and were manually released. We lost the signal of three individuals of $B$. b. spinosus and two individuals of $B$. viridis, probably due to transmitter failure. We removed the transmitters from all animals at the end of the study period.

The transmitter did not limit the toads' ability to access narrow shelters (mouse holes), to bury themselves up to $30 \mathrm{~cm}$ deep in the sand, or to shed skin. No other effect on the toads' behavior was observed. To avoid stress and bias in movements, animals were not dug out to verify their presence when hidden under shelter for less than a week.

Over 2 years (2005-2006), 7,417 locations of 114 B. b. spinosus and 134 B. viridis were gathered. For estimation of home range size, we used 6,071 locations of 67 B. b. spinosus and of 59 B. viridis. Thus, $41 \%$ of all radio-tracked individuals of $B$. b. spinosus and $56 \%$ of $B$. viridis were omitted for analyses because they lost the transmitter before a sufficien number of locations was collected to robustly estimate home range size.

Sixteen animals that lost the transmitter were recaptured and fitte again with radio transmitters. These animals were identifie by individual photos that were taken at firs capture.

Predation among all animals tracked in 2 years was low: out of 114 tracked B. b. spinosus, 3 individuals (2.6\%) were probably killed by herons or minks, whereas out of 134 tracked B. viridis, 8 individuals (5.9\%) were killed by snakes (Natrix natrix). Two individuals of B. viridis died, probably due to desiccation.

\section{Background and Results of the Information-Theoretic Approach Used}

Eleven candidate models were formulated based on previous studies and our present fiel observations to address the three hypotheses (table B3). Models 1-3 hypothesized that habitat factors (habitat richness, area of large 
wood deposits, home range temperature) determine home range size (hypothesis 1). Model 7 hypothesized that biotic factors (prey density, competition) determine home range size. Models 5, 6, and 8 hypothesized that both habitat and biotic factors determine home range size (hypothesis 2). Models 9-11 hypothesized that individual factors (body mass, sex, animal identity) determined home range size (hypothesis 3 ).

Models 1 and 2 were nested within model 3 to evaluate the relative contribution of the preferred habitat type (area of large wood deposits; see table B1), habitat richness, and home range temperature to variance in home range size. Each model, except model 10, included the number of locations to correct for sampling bias. We preferred to use the number of locations as a covariate instead of estimating home ranges with equal numbers of randomly selected locations, as proposed by Börger et al. (2006a) and Fieberg (2007). The former approach allowed us to quantify the separate effect of sampling bias. In each model, sex was used as a factor to correct for its potential effect on home range size. Emphasis was put on minimizing the set of factors and number of models to avoid bias in model selection. Interactions between factors were excluded because of the rather small sample size and to avoid overfitte models.

For home range calculation, we used data of both years, taking individuals as sample units. For model selection, we used data from 2006 because prey density was not sampled in 2005. Candidate models were fitte with general linear models (family $=$ Gaussian, link = identity) in $\mathrm{R}$, version 2.4.0 (R Development Core Team 2005), separately per species and scale using the same sample size (Anderson and Burnham 2002). All factors were $z$ standardized before to analysis. Home range size was log transformed to assure normally distributed residuals. One outlier (Cook's distance $>1$ ) was removed.

\section{Hypothesis 1: Habitat Factors Control the Size of 50\% Core Areas}

For B. b. spinosus, the three top-ranked models that were best supported by the data included the factors habitat richness, home range temperature, and prey density (table B4). The top-ranked model (no. 6) was twice as well supported as the second-ranked model (no. 5) and seven times better supported than the third-ranked model (no. 4; see evidence ratios, table B4). The effect of prey density on its $50 \%$ core area was almost six times larger than was the effect of habitat richness (table B5). For B. b. spinosus, hypothesis 1 was partly supported, because both habitat factors (habitat richness) and biotic factors (prey density) determined the $50 \%$ core area. For $B$. viridis, the best selected model (no. $1 ; \omega_{i}>0.9$ ) contained the factor area of large wood deposits (table B4), which solely determined its $50 \%$ core area (table B5), partly supporting hypothesis 1 . For both species, the factor home range temperature was poorly supported (confidenc intervals included 0; table B5), contrasting with our hypothesis.

\section{Hypothesis 2: Biotic Factors Control the Size of 95\% Home Ranges}

For B. b. spinosus, although the three top-ranked models (4, 5, and 7; sum of $\left.\omega_{i}>0.9\right)$ contained the factors home range temperature, prey density, and competition (table B4), prey density alone determined the $95 \%$ home range (table B5), partly supporting hypothesis 2 . In contrast, for $B$. viridis, the three top-ranked models (2, 3, and 6) contained habitat richness, area of large wood deposits, home range temperature, and prey density $\left(\omega_{i}>0.9\right.$; table B4). For B. viridis, hypothesis 2 was partly supported as both habitat factors (habitat richness) and biotic factors (prey density) predicted the size of the $95 \%$ home ranges (table B5), though confidenc intervals included 0 . Competition poorly explained the variation in $95 \%$ home ranges of both species (confidenc intervals included 0 ; table B5), contrasting with our hypothesis.

\section{Hypothesis 3: The Effects of Individual Factors Are Outweighed by the Effects of Habitat and Biotic Factors}

All individual factors (models 9-11) poorly predicted variation in the size of $50 \%$ core areas and $95 \%$ home ranges (confidenc intervals included 0; tables B4, B5), fully supporting hypothesis 3. Results were consistent when using the number of weeks instead the number of locations to correct for sampling bias (table B6). In summary, the most important home range-size determinants were prey density, habitat structure (habitat richness and area of large wood deposits), and temperature. 
App. B from L. Indermaur et al., "Determining Individual Space Use"

\section{Table B1}

Ranking order of preferred habitat types from compositional analysis separated for both species and the $50 \%$ core area (50) and the $95 \%$ home range (95)

\begin{tabular}{|c|c|c|c|c|c|c|c|c|c|c|c|c|c|c|c|c|c|c|}
\hline Species, scale & 1 & & 2 & & 3 & & 4 & & 5 & & 6 & & 7 & $n$ & $\lambda$ & $\chi^{2}$ & $P$ & $\mathrm{df}$ \\
\hline \multicolumn{19}{|c|}{ Bufo bufo spinosus: } \\
\hline 50 & ERO & $>$ & ISL-E & $=$ & ISL & $>$ & LWD & $=$ & $\mathrm{PD}$ & $>$ & GRA & $>$ & PL & 54 & .27 & 70.3 & $<.001$ & 6 \\
\hline 95 & LWD & $>$ & ISL-E & $>$ & ERO & $>$ & GRA & $>$ & PD & $>$ & ISL & $>$ & PL & 54 & .39 & 50.9 & $<.001$ & 7 \\
\hline \multicolumn{19}{|l|}{ Bufo viridis: } \\
\hline 50 & LWD & $\gg>$ & GRA & $=$ & ISL-E & $=$ & RIP-E & $>$ & PL & $>$ & PD & $>$ & ERO & 59 & .16 & 110.0 & $<.001$ & 6 \\
\hline 95 & LWD & $\gg>$ & GRA & $>$ & RIP-E & $>$ & ISL-E & $>$ & ERO & $>$ & PL & $>$ & PD & 59 & .12 & 96.8 & $<.001$ & 6 \\
\hline
\end{tabular}

\section{Table B2}

Results of a principal component analysis summarizing variation in landscape measures, separated by species, the $50 \%$ core area, and the $95 \%$ home range

\begin{tabular}{|c|c|c|c|c|}
\hline \multirow[b]{2}{*}{ Species, factor } & \multicolumn{2}{|c|}{$\begin{array}{c}50 \% \text { core area } \\
\text { component }\end{array}$} & \multicolumn{2}{|c|}{$\begin{array}{l}95 \% \text { home range } \\
\text { component }\end{array}$} \\
\hline & 1 & 2 & 1 & 2 \\
\hline \multicolumn{5}{|l|}{ Bufo bufo spinosus: } \\
\hline Richness & .97 & -.04 & .94 & .05 \\
\hline No. patches & .96 & -.13 & .91 & .05 \\
\hline Edge length & .89 & .33 & .74 & .61 \\
\hline Contagion index & .01 & .99 & .02 & .99 \\
\hline$\%$ variance explained & 66.45 & 27.44 & 63.24 & 26.85 \\
\hline \multicolumn{5}{|l|}{ Bufo viridis: } \\
\hline Richness & .92 & & .90 & \\
\hline No. patches & .88 & & .89 & \\
\hline Edge length & .87 & & .73 & \\
\hline Contagion index & .45 & & .71 & \\
\hline$\%$ variance explained & 64.51 & & 66.25 & \\
\hline
\end{tabular}

Table B3

Candidate models used for predicting home range size (log-HRS)

\begin{tabular}{|c|c|c|c|c|}
\hline Model & Facto & & Explanation/key features & Reference \\
\hline 1 & Wood & $+N+\operatorname{sex}$ & $\begin{array}{l}\text { Partial habitat structure (area of large } \\
\text { wood deposits, which is the } \\
\text { preferred habitat) }\end{array}$ & $\begin{array}{l}\text { Pasinelli 2000; McLoughlin et al. } \\
\text { 2003; Buner et al. } 2005\end{array}$ \\
\hline 2 & Wood $+\mathrm{Ri}$ & $+N+\operatorname{sex}$ & $\begin{array}{l}\text { Total habitat structure (area of large } \\
\text { wood deposits plus habitat } \\
\text { richness) }\end{array}$ & Kie et al. 2002 \\
\hline 3 & Wood $+\mathrm{Ri}+\mathrm{T}$ & $+N+\operatorname{sex}$ & $\begin{array}{l}\text { Total habitat structure and habitat } \\
\text { temperature }\end{array}$ & $\begin{array}{c}\text { Schwarzkopf and Alford 1996; } \\
\text { Seebacher and Alford } 2002\end{array}$ \\
\hline 4 & Prey & $+N+\operatorname{sex}$ & Prey density & McNab 1963; Ebersole 1980 \\
\hline 5 & Prey $+\mathrm{T}$ & $+N+\operatorname{sex}$ & Prey density and habitat temperature & Pereira et al. 2002 \\
\hline 6 & Prey $+\mathrm{T}+\mathrm{Ri}$ & $+N+\operatorname{sex}$ & $\begin{array}{l}\text { Prey density, habitat temperature and } \\
\text { habitat structure }\end{array}$ & $\begin{array}{l}\text { Tufto et al. 1996; Lombardi et al. } \\
2007\end{array}$ \\
\hline 7 & Prey + Co & $+N+\operatorname{sex}$ & Prey density and competition & Hixon 1980 \\
\hline
\end{tabular}


App. B from L. Indermaur et al., "Determining Individual Space Use"

Table B3 (Continued)

\begin{tabular}{|c|c|c|c|c|}
\hline Model & Factor & & Explanation/key features & Reference \\
\hline 8 & Prey $+\mathrm{Co}+\mathrm{Ri}$ & $+N+\operatorname{sex}$ & $\begin{array}{l}\text { Prey density, competition and habitat } \\
\text { structure }\end{array}$ & $\begin{array}{l}\text { Burt 1943; Kleeberger 1985; Smyers } \\
\text { et al. } 2002\end{array}$ \\
\hline 9 & M & $+N+\operatorname{sex}$ & Body mass not important & $\begin{array}{l}\text { Relyea et al. 2000; Said and Servanty } \\
2005\end{array}$ \\
\hline 10 & $\mathrm{~N}$ & $+N+\operatorname{sex}$ & No. locations (sampling bias) & Börger et al. 2006a; Fieberg 2007 \\
\hline 11 & A & $+N+\operatorname{sex}$ & $\begin{array}{l}\text { Differences in quality among animals } \\
\text { not important }\end{array}$ & Steury and Murray 2003 \\
\hline
\end{tabular}

Note: See table 1 for abbreviations of factors. The number of locations $(N)$ was used as a covariate in every model (except model 10) to correct for sampling bias. Similarly, sex was used in every model to correct for its potential effect on home range size.

\section{Table B4}

Model selection results for predicting intraspecifi variation in log-home range size, sorted after differences between Akaike's small-sample information criterion $(\triangle \mathrm{AICc})$, separately by species, the $50 \%$ core area, and the $95 \%$ home range

\begin{tabular}{|c|c|c|c|c|c|c|c|c|}
\hline Model no. & Models & $R^{2}$ & $K$ & LL & $\mathrm{AICc}$ & $\Delta \mathrm{AICc}$ & $\omega_{i}$ & ER \\
\hline \multicolumn{9}{|c|}{ Bufo bufo spinosus, $50 \%$ core area $(n=23)$ : } \\
\hline 6 & Prey $+\mathbf{R i}+\mathbf{T}$ & .992 & 7 & 45.9 & -70.3 & .0 & .585 & 1 \\
\hline 5 & Prey $+\mathbf{T}$ & .990 & 6 & 43.1 & -69.0 & 1.3 & .312 & 2 \\
\hline 4 & Prey & .987 & 5 & 40.0 & -66.4 & 3.9 & .085 & 7 \\
\hline 7 & Prey + Co & .987 & 6 & 40.0 & -62.7 & 7.6 & .013 & 44 \\
\hline 8 & Prey $+\mathrm{Ri}+\mathrm{Co}$ & .989 & 7 & 41.1 & -60.8 & 9.5 & .005 & 117 \\
\hline 3 & Wood $+\mathrm{Ri}+\mathrm{T}$ & .935 & 7 & 21.1 & -20.7 & 49.6 & .000 & 6. $E+10$ \\
\hline 2 & Wood + Ri & .916 & 6 & 18.2 & -19.2 & 51.1 & .000 & 1. $E+11$ \\
\hline 1 & Wood & .615 & 5 & .7 & 12.1 & 82.4 & .000 & 8. $E+17$ \\
\hline 10 & $\mathrm{~N}$ & .143 & 4 & -8.5 & 27.2 & 97.5 & .000 & 1. $E+21$ \\
\hline 9 & M & .112 & 5 & -8.1 & 30.2 & 100.5 & .000 & 7. $E+21$ \\
\hline 11 & A & .150 & 5 & -8.4 & 30.3 & 100.6 & .000 & 7. $E+21$ \\
\hline \multicolumn{9}{|c|}{ B. b. spinosus, $95 \%$ home range $(n=22)$ : } \\
\hline 4 & Prey & .988 & 6 & 31.8 & -63.4 & .0 & .599 & 1 \\
\hline 5 & Prey $+\mathbf{T}$ & .989 & 7 & 33.1 & -60.8 & 1.8 & .245 & 2 \\
\hline 7 & Prey + Co & .984 & 5 & 28.3 & -60.4 & 3.1 & .125 & 5 \\
\hline 6 & Prey $+\mathrm{Ri}+\mathrm{T}$ & .984 & 6 & 28.7 & -56.7 & 6.2 & .027 & 22 \\
\hline 8 & Prey $+\mathrm{Ri}+\mathrm{Co}$ & .985 & 7 & 29.0 & -56.2 & 10.0 & .004 & 147 \\
\hline 2 & Wood + Ri & .769 & 6 & -.7 & 12.8 & 65.1 & .000 & 1. $E+14$ \\
\hline 3 & Wood $+\mathrm{Ri}+\mathrm{T}$ & .791 & 7 & .4 & 14.9 & 67.3 & .000 & 4. $E+14$ \\
\hline 1 & Wood & .635 & 5 & -5.7 & 21.3 & 71.3 & .000 & 3. $E+15$ \\
\hline 9 & M & .352 & 5 & -12.1 & 33.3 & 83.9 & .000 & 2. $\mathrm{E}+18$ \\
\hline 11 & $\mathrm{~A}$ & .252 & 5 & -11.7 & 34.0 & 84.1 & .000 & 2. $E+18$ \\
\hline 10 & $\mathrm{~N}$ & .211 & 4 & -14.2 & 34.5 & 84.8 & .000 & 3. $E+18$ \\
\hline \multicolumn{9}{|c|}{ Bufo viridis, $50 \%$ core area $(n=24)$ : } \\
\hline 1 & Wood & .916 & 5 & 4.5 & 4.3 & .0 & .798 & 1 \\
\hline 2 & Wood + Ri & .918 & 6 & 4.7 & 7.5 & 3.2 & .162 & 5 \\
\hline 3 & Wood $+\mathrm{Ri}+\mathrm{T}$ & .922 & 7 & 5.4 & 10.2 & 6.0 & .041 & 20 \\
\hline 4 & Prey & .783 & 5 & -6.9 & 27.1 & 22.9 & .000 & 9. $E+04$ \\
\hline 5 & Prey $+\mathrm{T}$ & .783 & 6 & -6.9 & 30.7 & 26.4 & .000 & 6. $E+05$ \\
\hline 7 & Prey + Co & .783 & 6 & -6.9 & 30.7 & 26.5 & .000 & 6. $E+05$ \\
\hline 6 & Prey $+\mathrm{Ri}+\mathrm{T}$ & .794 & 7 & -6.3 & 33.6 & 29.3 & .000 & 2. $E+06$ \\
\hline 8 & Prey $+\mathrm{Ri}+\mathrm{Co}$ & .792 & 7 & -6.4 & 33.8 & 29.5 & .000 & 3. $E+06$ \\
\hline 10 & $\mathrm{~N}$ & .126 & 4 & -23.6 & 57.3 & 53.1 & .000 & 3. $E+11$ \\
\hline 9 & M & .166 & 5 & -22.1 & 57.6 & 53.4 & .000 & 4. $E+11$ \\
\hline
\end{tabular}


App. B from L. Indermaur et al., "Determining Individual Space Use"

Table B4 (Continued)

\begin{tabular}{|c|c|c|c|c|c|c|c|c|}
\hline Model no. & Models & $R^{2}$ & $K$ & LL & $\mathrm{AICc}$ & $\Delta \mathrm{AICc}$ & $\omega_{i}$ & ER \\
\hline 11 & A & .129 & 5 & -23.6 & 60.5 & 56.2 & .000 & 2. $\mathrm{E}+12$ \\
\hline \multicolumn{9}{|c|}{ B. viridis, $95 \%$ home range $(n=28)$ : } \\
\hline 2 & Wood + Ri & .784 & 7 & 2.8 & -4.9 & .0 & .400 & 1 \\
\hline 3 & Wood $+\mathbf{R i}+\mathbf{T}$ & .780 & 7 & 3.0 & -5.2 & 6 & .290 & 1 \\
\hline 6 & Prey $+\mathbf{R i}+\mathbf{T}$ & .716 & 5 & 1.9 & -8.9 & 1.2 & .214 & 2 \\
\hline 8 & Prey $+\mathbf{R i}+\mathbf{C o}$ & .719 & 6 & 1.8 & -8.7 & 4.1 & .051 & 8 \\
\hline 1 & Wood & .717 & 6 & -3.7 & -8.9 & 4.4 & .045 & 9 \\
\hline 4 & Prey & .593 & 6 & -5.2 & -14.1 & 14.9 & .000 & 1,741 \\
\hline 5 & Prey $+\mathrm{T}$ & .511 & 5 & -3.7 & -16.8 & 17.1 & .000 & 5,050 \\
\hline 7 & Prey $+\mathrm{Co}$ & .610 & 7 & -4.7 & -13.5 & 17.2 & .000 & 5,343 \\
\hline 10 & $\mathrm{~N}$ & .273 & 5 & -14.4 & -19.4 & 22.7 & .000 & 9. $E+04$ \\
\hline 9 & M & .332 & 4 & -13.8 & -21.3 & 23.1 & .000 & 1. $E+05$ \\
\hline 11 & A & .334 & 5 & -14.0 & -21.3 & 26.0 & .000 & 4. $E+05$ \\
\hline
\end{tabular}

Note: See table 1 for abbreviations of factors. The top-ranked model, with $\Delta \mathrm{AICc}=0$, best approximates the data, and models with $\Delta \mathrm{AICc} \leq 2$ are considered to receive substantial support from the data. The number of animals $(n)$, the coefficien of determination $\left(R^{2}\right)$, number of factors $(K), \log$ likelihood (LL), model weights $\left(\omega_{i}\right)$ and evidence ratios (ERs) are given. When one model receives $\omega_{i} \geq 0.9$, there is no model selection uncertainty apparent. ERs are the ratio of model weights of a particular model in relation to the top-ranked model. Models in boldface (confi ence set: sum of $\omega_{i}>0.9$ ) were used for model averaging.

Table B5

Model-averaged factors of intraspecifi variation in home range size for both species in the $50 \%$ core area and the $95 \%$ home range

\begin{tabular}{|c|c|c|c|c|c|c|c|c|c|c|}
\hline \multirow[b]{2}{*}{ Factors } & \multicolumn{5}{|c|}{$50 \%$ core area } & \multicolumn{5}{|c|}{$95 \%$ home range } \\
\hline & $\beta$ & SE & $\mathrm{CV}$ & LCI & UCI & $\beta$ & SE & $\mathrm{CV}$ & LCI & $\mathrm{UCI}$ \\
\hline \multicolumn{11}{|c|}{ Bufo bufo spinosus: } \\
\hline Co & & & & & & -.025 & .019 & .764 & -.063 & .012 \\
\hline $\mathrm{N}$ & .012 & .026 & 2.132 & -.040 & .064 & -.003 & .047 & 14.450 & -.096 & .089 \\
\hline Prey & .333 & .048 & .145 & .236 & .430 & .461 & .056 & .121 & .352 & .571 \\
\hline $\mathrm{Ri}$ & .059 & .028 & .468 & .004 & .114 & -.040 & .028 & .704 & -.094 & .015 \\
\hline Sex & .039 & .065 & 1.676 & -.092 & .169 & .008 & .105 & 12.392 & -.197 & .214 \\
\hline $\mathrm{T}$ & .090 & .063 & .696 & -.035 & .215 & & & & & \\
\hline \multicolumn{11}{|c|}{ Bufo viridis: } \\
\hline Co & & & & & & .032 & .180 & 5.641 & -.321 & .384 \\
\hline Wood & .705 & .125 & .177 & .456 & .954 & & & & & \\
\hline $\mathrm{N}$ & .146 & .137 & .942 & -.129 & .420 & .174 & .284 & 1.629 & -.382 & .730 \\
\hline Prey & & & & & & .429 & .289 & .673 & -.137 & .996 \\
\hline $\mathrm{Ri}$ & .038 & .065 & 1.739 & -.093 & .168 & .214 & .160 & .744 & -.098 & .527 \\
\hline Sex & -.110 & .204 & 1.851 & -.519 & .298 & -.050 & .582 & 11.590 & -1.192 & 1.091 \\
\hline $\mathrm{T}$ & & & & & & -.057 & .069 & 1.202 & -.192 & .078 \\
\hline
\end{tabular}

Note: See table 1 for abbreviations of factors. All factors were standardized before analysis. Unconditional effect size $(\beta=$ slopes of factors in general linear models) with standard error (SE), coefficien of variation $(|\mathrm{CV}|=\mathrm{SE} / \beta)$, and lower (LCI) and upper (UCI) confidenc intervals $(\beta \pm 2 \mathrm{SE}$ ). $\beta, \mathrm{SE}$, and $\mathrm{CV}$ are based on a confidenc model set (summarized weights $\geq 0.90$ ). Factors not listed (see table 1) or without values were not included in the model set used for model averaging. Factors that did not include 0 in confi ence intervals are considered important (bold). 
App. B from L. Indermaur et al., "Determining Individual Space Use"

Table B6

Model-averaged factors of intraspecifi variation in home range size for both species in the $50 \%$ core area and the $95 \%$ home range

\begin{tabular}{|c|c|c|c|c|c|c|c|c|c|c|}
\hline \multirow[b]{3}{*}{ Factors } & \multicolumn{10}{|c|}{$95 \%$ home range } \\
\hline & \multicolumn{5}{|c|}{ Bufo bufo spinosus } & \multicolumn{5}{|c|}{ Bufo viridis } \\
\hline & $\beta$ & SE & $|\mathrm{CV}|$ & LCI & $\mathrm{UCI}$ & $\beta$ & $\mathrm{SE}$ & $|\mathrm{CV}|$ & LCI & UCI \\
\hline $\mathrm{Co}$ & -.026 & .019 & .720 & -.064 & .011 & -.007 & .089 & 12.535 & -.181 & .167 \\
\hline Week & .013 & .050 & 3.862 & -.086 & .112 & .175 & .211 & 1.210 & -.240 & .590 \\
\hline Prey & .453 & .058 & .129 & .338 & .568 & .414 & .203 & .491 & .015 & .814 \\
\hline $\mathrm{Ri}$ & -.032 & .027 & .834 & -.086 & .020 & .247 & .155 & .628 & -.057 & .551 \\
\hline Sex & -.001 & .102 & 174.325 & -.202 & .201 & -.079 & .434 & 5.427 & -.930 & .770 \\
\hline $\mathrm{T}$ & & & & & & -.115 & .068 & .592 & -.250 & .018 \\
\hline
\end{tabular}

Note: Here, the number of weeks (Week) was used to correct for sampling bias, while in table B5 the number of locations collected was used to correct for sampling bias. See table 1 for abbreviations of other factors. All factors were standardized before analysis. Unconditional effect size $(\beta=$ slopes of factors in general linear models) with standard error (SE), coefficien of variation $(|\mathrm{CV}|=\mathrm{SE} / \beta$ ), and lower (LCI) and upper (UCI) confi ence intervals $(\beta \pm 2 \mathrm{SE}) . \beta$, SE, and $\mathrm{CV}$ are based on a confidenc model set (summarized weights $\geq 0.90$ ). Factors not listed (see table 1) or without values were not included in the model set used for model averaging. Factors that did not include 0 in confide ce intervals are considered important (bold).

\section{Table B7}

Correlation matrix of factors used in candidate models for predicting log-home range size (HRS), separated by species, the $50 \%$ core area, and the $95 \%$ home range

\begin{tabular}{|c|c|c|c|c|c|c|c|c|c|c|}
\hline Factors & $n$ & $\log$-HRS & $\mathrm{Ri}$ & Wood & Prey & Co & M & $\mathrm{T}$ & $\mathrm{N}$ & Week \\
\hline \multicolumn{11}{|c|}{ Bufo bufo spinosus, $50 \%$ core area: } \\
\hline Log-HRS & 54 & 1.000 & .938 & .710 & .993 & -.331 & -.047 & .432 & .345 & .272 \\
\hline $\mathrm{Ri}$ & 54 & & 1.000 & .708 & .942 & -.259 & -.068 & .262 & .181 & .141 \\
\hline Wood & 54 & & & 1.000 & .777 & -.167 & -.113 & .180 & .016 & -.084 \\
\hline Prey & 23 & & & & 1.000 & -.343 & -.061 & .380 & .300 & .243 \\
\hline Co & 54 & & & & & 1.000 & -.198 & .017 & .114 & -.007 \\
\hline M & 51 & & & & & & 1.000 & -.450 & .169 & .101 \\
\hline $\mathrm{T}$ & 54 & & & & & & & 1.000 & .375 & .238 \\
\hline $\mathrm{N}$ & 54 & & & & & & & & 1.000 & .818 \\
\hline Week & 54 & & & & & & & & & 1.000 \\
\hline \multicolumn{11}{|c|}{ B. b. spinosus, $95 \%$ home range: } \\
\hline Log-HRS & 54 & 1.000 & .760 & .686 & .992 & -.215 & -.265 & .549 & .261 & .408 \\
\hline $\mathrm{Ri}$ & 54 & & 1.000 & .611 & .774 & -.279 & -.101 & .306 & .081 & .216 \\
\hline Wood & 54 & & & 1.000 & .705 & -.120 & -.265 & .274 & .011 & .163 \\
\hline Prey & 22 & & & & 1.000 & -.124 & -.284 & .560 & .259 & .414 \\
\hline Co & 54 & & & & & 1.000 & .094 & -.119 & .093 & .037 \\
\hline M & 51 & & & & & & 1.000 & -.539 & .232 & .179 \\
\hline $\mathrm{T}$ & 54 & & & & & & & 1.000 & .141 & .323 \\
\hline $\mathrm{N}$ & 54 & & & & & & & & 1.000 & .802 \\
\hline Week & 54 & & & & & & & & & 1.000 \\
\hline \multicolumn{11}{|c|}{ Bufo viridis, $50 \%$ core area: } \\
\hline Log-HRS & 59 & 1.000 & .639 & .940 & .839 & -.022 & .103 & .556 & .182 & .159 \\
\hline $\mathrm{Ri}$ & 59 & & 1.000 & .614 & .596 & -.135 & .402 & .574 & .096 & -.159 \\
\hline Wood & 59 & & & 1.000 & .834 & -.127 & .181 & .579 & .045 & .088 \\
\hline Prey & 26 & & & & 1.000 & .015 & .314 & .557 & .149 & .176 \\
\hline Co & 59 & & & & & 1.000 & -.213 & -.166 & -.318 & .106 \\
\hline M & 57 & & & & & & 1.000 & .314 & -.136 & .142 \\
\hline $\mathrm{T}$ & 59 & & & & & & & 1.000 & .074 & .027 \\
\hline $\mathrm{N}$ & 59 & & & & & & & & 1.000 & .490 \\
\hline
\end{tabular}


App. B from L. Indermaur et al., "Determining Individual Space Use"

Table B7 (Continued)

\begin{tabular}{|c|c|c|c|c|c|c|c|c|c|c|}
\hline Factors & $n$ & $\log$-HRS & $\mathrm{Ri}$ & Wood & Prey & Co & M & $\mathrm{T}$ & $\mathrm{N}$ & Week \\
\hline Week & 59 & & & & & & & & & 1.000 \\
\hline \multicolumn{11}{|c|}{ B. viridis, $95 \%$ home range: } \\
\hline Log-HRS & 59 & 1.000 & .583 & .536 & .851 & -.005 & .003 & .239 & .538 & .343 \\
\hline $\mathrm{Ri}$ & 59 & & 1.000 & .383 & .427 & -.438 & -.048 & .552 & .287 & .138 \\
\hline Wood & 59 & & & 1.000 & .698 & .094 & .127 & .380 & .169 & .185 \\
\hline Prey & 29 & & & & 1.000 & .027 & .037 & .351 & .379 & .248 \\
\hline Co & 59 & & & & & 1.000 & .087 & -.308 & -.126 & .407 \\
\hline M & 57 & & & & & & 1.000 & -.004 & .148 & .234 \\
\hline $\mathrm{T}$ & 59 & & & & & & & 1.000 & .140 & .064 \\
\hline $\mathrm{N}$ & 59 & & & & & & & & 1.000 & .609 \\
\hline Week & 59 & & & & & & & & & 1.000 \\
\hline
\end{tabular}

Table B8

Distribution of locations, classifie as "resting" or "foraging," in 50\% core areas and $95 \%$ home ranges

\begin{tabular}{|c|c|c|c|c|c|c|c|c|}
\hline & \multicolumn{4}{|c|}{ Bufo bufo spinosus } & \multicolumn{4}{|c|}{ Bufo viridis } \\
\hline & \multirow[b]{2}{*}{$n$} & \multirow[b]{2}{*}{$\%$} & \multicolumn{2}{|c|}{$n(\%$ of total $n)$} & \multirow[b]{2}{*}{$n$} & \multirow[b]{2}{*}{$\%$} & \multicolumn{2}{|c|}{$n(\%$ of total $n)$} \\
\hline & & & Core area & Home range & & & Core area & Home range \\
\hline Seen & 1,116 & 35.1 & 13.7 & 31.7 & 1,152 & 45.1 & 17.4 & 42.7 \\
\hline Not seen & 2,063 & 64.9 & 36.7 & 61.8 & 1,404 & 54.9 & 38.5 & 54.3 \\
\hline Total & 3,179 & 100.0 & 50.3 & 93.6 & 2,556 & 100.0 & 55.9 & 97.0 \\
\hline Seen at day & 406 & 36.4 & 16.2 & 33.2 & 374 & 32.5 & 19.4 & 31.7 \\
\hline Seen at night & 710 & 63.6 & 22.7 & 57.3 & 776 & 67.5 & 19.1 & 63.0 \\
\hline Total & 1,116 & 100.0 & 38.9 & 90.4 & 1,150 & 100.0 & 38.5 & 94.8 \\
\hline Not seen at day & 1,329 & 64.4 & 37.0 & 61.2 & 985 & 70.3 & 49.8 & 69.5 \\
\hline Not seen at night & 734 & 35.6 & 19.5 & 34.0 & 417 & 29.7 & 20.3 & 29.4 \\
\hline Total & 2,063 & 100.0 & 56.5 & 95.2 & 1,402 & 100.0 & 70.0 & 98.9 \\
\hline Seen moving & 156 & 19.6 & 5.4 & 17.2 & 342 & 43.1 & 9.3 & 40.2 \\
\hline Seen sitting & 639 & 80.4 & 31.9 & 72.5 & 451 & 56.9 & 27.7 & 55.0 \\
\hline Total & 795 & 100.0 & 37.4 & 89.7 & 793 & 100.0 & 37.1 & 95.2 \\
\hline Seen moving at day & 23 & 14.7 & 6.4 & 14.1 & 13 & 3.8 & 1.5 & 3.8 \\
\hline Seen moving at night & 133 & 85.3 & 21.2 & 73.7 & 329 & 96.2 & 20.2 & 89.5 \\
\hline Total & 156 & 100.0 & 27.6 & 87.8 & 342 & 100.0 & 21.6 & 93.3 \\
\hline Seen sitting at day & 274 & 42.9 & 16.7 & 38.2 & 242 & 53.7 & 33.0 & 52.5 \\
\hline Seen sitting at night & 365 & 57.1 & 23.0 & 52.0 & 209 & 46.3 & 15.7 & 44.1 \\
\hline Total & 639 & 100.0 & 39.7 & 90.1 & 451 & 100.0 & 48.8 & 96.7 \\
\hline
\end{tabular}

\section{Literature Cited Only In Appendix B}

Anderson, D. R., and K. P. Burnham. 2002. Avoiding pitfalls when using information-theoretic methods. Journal of Wildlife Management 66:912-918.

Börger, L., N. Franconi, G. De Michele, A. Gantz, F. Meschi, A. Manica, S. Lovari, and T. Coulson. $2006 a$. Effects of sampling regime on the mean and variance of home range size estimates. Journal of Animal Ecology 75:1493-1505.

Fieberg, J. 2007. Kernel density estimators of home range: smoothing and the autocorrelation red herring. Ecology 88:1059-1066. 
App. B from L. Indermaur et al., "Determining Individual Space Use"

Kleeberger, S. R. 1985. Influenc of intraspecifi density and cover on home range of a plethodontid salamander. Oecologia (Berlin) 66:404-410.

Pereira, M. E., J. Aines, and J. L. Scheckter. 2002. Tactics of heterothermy in eastern gray squirrels (Sciurus carolinensis). Journal of Mammalogy 83:467-477.

R Development Core Team. 2005. R: a language and environment for statistical computing. R Foundation for Statistical Computing, Vienna, Austria.

Smyers, S. D., M. J. Rubbo, V. R. Townsend, and C. C. Swart. 2002. Intra- and interspecifi characterizations of burrow use and defense by juvenile ambystomatid salamanders. Herpetologica 58:422-429. 